\title{
The effects of rice seed dressing with Paenibacillus yonginensis and silicon on crop development on South Korea's reclaimed tidal land
}

\author{
Eul-Su Choi ${ }^{\mathrm{a}, 1}$, Johan Sukweenadhi ${ }^{\mathrm{a}, 1}$, Yeon-Ju Kim ${ }^{\mathrm{a}, *}$, Ki Hong Jung ${ }^{\mathrm{b}}$, Sung-Cheol Koh ${ }^{\mathrm{c}}$, \\ Van-An Hoang ${ }^{\mathrm{a}}$, Deok-Chun Yang ${ }^{\mathrm{a}, \mathrm{d}, *}$ \\ a Graduate School of Biotechnology, College of Life Science, Kyung Hee University, Yongin 446-701, Republic of Korea \\ b Department of Plant Molecular Systems Biotechnology E' Crop Biotech Institute, Kyung Hee University, Republic of Korea \\ ${ }^{\mathrm{c}}$ Department of Environmental Engineering, Korea Maritime University, Busan, Republic of Korea \\ ${ }^{\mathrm{d}}$ Department of Oriental Medicinal Biotechnology, College of Life Science, Kyung Hee University, Yongin 446-701, Republic of Korea
}

\section{A R T I C L E I N F O}

\section{Article history:}

Received 27 November 2015

Received in revised form

29 December 2015

Accepted 8 January 2016

Available online 22 January 2016

\section{Keywords:}

PGPB

Seed improvement

Field test

Saline stress

GABA

\begin{abstract}
A B S T R A C T
A field trial to investigate the effects of plant growth promoting bacteria (PGPB) Paenibacillus yonginensis $\left(\mathrm{DCY}^{4} 4^{\mathrm{T}}\right.$ ) and/or $\mathrm{SiO}_{2}$ seed coating on rice growth (Oryza sativa $\mathrm{L}$.) was carried out on reclaimed tidal land in Taean County in South Korea. The field test was performed twice between May-October 2014 and May-October 2015, in a randomized complete block (RCB) design with three replications. Treatments consisted of: Mock, DCY84 ${ }^{\mathrm{T}}$-treated seeds, $\mathrm{SiO}_{2}$-coated seeds and $\mathrm{DCY} 84^{\mathrm{T}}-\mathrm{SiO}_{2}$-treated seeds and each treatment area covered approximately $300 \mathrm{~m}^{2}$. During the early developmental period of rice seedlings, the $\mathrm{SiO}_{2}$ coating without $\mathrm{DCY} 84^{\mathrm{T}}$ led to the most favorable 30 DAS rice seedling parameters. Moreover, the combination of $\mathrm{DCY} 84^{\mathrm{T}}$ and $\mathrm{SiO}_{2}$ treatments resulted in 2-fold greater fresh and dry weights of $60 \mathrm{DAS}$ rice seedlings compared to Mock seedlings. $\mathrm{DCY} 4^{\mathrm{T}}$ and $\mathrm{SiO}_{2}$, both individually and together, produced a greater grain yield and a greater total yield; specifically, $\mathrm{DCY} 84^{\mathrm{T}}$ and $\mathrm{SiO}_{2}$ treatments yielded a $73 \%$ and $70 \%$ increase in mass compared to Mock plants, respectively. Rice treated with both $\mathrm{DCY} 84^{\mathrm{T}}$ and $\mathrm{SiO}_{2}$ treatment contained the highest amount of $\mathrm{Al}, \mathrm{Fe}, \mathrm{Ca}$ and $\mathrm{Mg}$, which were $54 \%, 169 \%, 42 \%$ and $67 \%$ higher than the Mock rice, respectively. Remarkably, DCY84 ${ }^{\mathrm{T}}$ treatment had the most phosphate $[\mathrm{P}]$, potassium $[\mathrm{K}]$ and total nitrogen $[\mathrm{T}-\mathrm{N}]$. $\mathrm{DCY} 84^{\mathrm{T}}$ and/or $\mathrm{SiO}_{2}$ treatment highly increased the whole kernel percentage. Thus, lower its broken kernel percentage to $9.60-24.58 \%$. The protein content of the grain with both treatments was $7.2 \%$, which was greater than that of the Mock grain (6.0\%). The content of chlorophyll a, b and carotinoid in the rice leaves which were treated with silica and DCY84 has increased more than the mock without treatment. After harvest, the GABA content of brown rice was increased to 1.9-fold (2014), 1.5 fold (2015) compared to mock grain, respectively. Overall, DCY84 ${ }^{\mathrm{T}}$ treatment and $\mathrm{SiO}_{2}$ coating can be useful methods for promoting growth of rice under conditions of saline stress. Results from other laboratory trials and greenhouse experiments are also provided.
\end{abstract}

(c) 2016 Published by Elsevier B.V.

\section{Introduction}

The exponential growth of the human population demands more food and thus enhanced crop production. During the 1960's, the Green Revolution was largely responsible for increasing food supply. Currently, two alternatives exist for increasing cereal pro-

\footnotetext{
* Corresponding authors at: Department of Oriental Medicinal Biotechnology, College of Life Science, Kyung Hee University, Yongin 446-701, Republic of Korea. Fax: +82312022687 .

E-mail addresses: yeonjukim@khu.ac.kr (Y.-J. Kim), dcyang@khu.ac.kr (D.-C. Yang).

1 These authors contributed equally to this work.
}

duction: (1) expanding farming into areas that are currently not used for food production or (2) attaining a higher yield per unit of land area in existing agricultural areas (Linquist et al., 2011). In South Korea, because the available farmland had been decreasing due to urbanization and industrialization, farming on reclaimed tidal land is one of the country's efforts to produce more food. However, agricultural activities on reclaimed tidal land are generally difficult due to high salinity and low amounts of nutrients (Cho et al., 2008). A "saline soil" is usually defined as soil in which the electrical conductivity (EC) of the saturation extract $\left(E_{e}\right)$ in the root zone is more than $4 \mathrm{dS} \mathrm{m}^{-1}$ at $25^{\circ} \mathrm{C}$ (equal to $40 \mathrm{mM} \mathrm{NaCl}$ ) and the exchangeable sodium is less than $15 \%$. The yield of most crop plants is reduced at this $\mathrm{EC}_{\mathrm{e}}$, though many crops exhibit yield 
reduction at lower $\mathrm{EC}_{\mathrm{e}} \mathrm{s}$ (Jamil et al., 2011). Indeed, excess saline has been known to suppress plant growth (Paul, 2012); it affects almost all aspects of plant development (germination, vegetative growth, reproductive development, etc.,), through osmotic and oxidative stress (Bano and Fatima, 2009), which can decrease enzyme activity (Seckin et al., 2009); inhibit DNA, RNA and protein synthesis (Javid et al., 2011; Tabur and Demir, 2010); cause ion toxicity and lead to nutrient deficiency (e.g., N, Ca, K, P, Fe and Zn) (Bano and Fatima, 2009).

Indirect stimulation of Plant growth-promoting bacteria (PGPB) is related to inducing the plant's systemic resistant responses against biotic (as biocontrol agents) and abiotic stress (as plant strengthener) (Ahmad et al., 2008; Yang et al., 2009). In addition, PGPB also can be used to achieve enhancement of plant growth (as plant growth promoter) and nutrient management (as biofertilizers) (Nia et al., 2012; Ramadoss et al., 2013). The use of microorganism inoculant continues to be an area of rapidly growing research because it is both ecologically and economically relevant (Berg, 2009). An excellent review about these bacteria inoculants has recently been published (Pérez-Montãno et al., 2014). Meanwhile, Acetobacter, Azospirillum, Azotobacter, Bacillus, Burkholderia, Pseudomonas, some members of the Enterobacteriaceae family and, recently, Paenibacillus are known for their ability to promote plant growth (Bashan et al., 2004; Hayat et al., 2010). The genus Paenibacillus has been shown to fix atmospheric nitrogen, produce siderophores and solubilize minerals in soil (Timmusk 2003). To date, several Paenibacillus species have been reported to be PGPB such as Paenibacillus polymyxa (Lebuhn et al., 1997; Timmusk and Wagner, 1999; Raza et al., 2009), Paenibacillus brasiliensis (von der Weid et al., 2002), Paenibacillus borealis (Elo et al., 2001; Egamberdiyeva, 2005), Paenibacillus illinoisensis (Jung et al., 2005), Paenibacillus elgii (Das et al., 2010), Paenibacillus ehimensis (Naing et al., 2013) and recently Paenibacillus yonginensis (Sukweenadhi et al., 2015). Numerous field experiments have demonstrated the potential for single strain inoculant biofertilizers to reduce fertilizer requirements and enhance yields of rice, including applications of azospirilla, pseudomonas, enterobacteria and rhizobia such as: Azospirillum brasilense Wb3 and Azospirillum lipoferum N4 (Malik et al., 2002), Pseudomonas fluorescens Pf1 (Vidhyaskaran et al., 1997), Burkholderia vietnamiensis TVV75 (Trân Van et al., 2000) and Rhizobium leguminosarum bv trifolii E11 (Yanni et al., 2001).

Silicon ( $\mathrm{Si}$ ) is a primary constituent of the Earth's crust that can easily be found in almost all soil types. However, Si uptake by plants is faster than the Si cycle in nature (Guntzer et al., 2012).Si-deficient plants are often anatomically weaker and exhibit abnormal growth; thus, they are more susceptible to biotic and abiotic stress compared with Si-rich plants (Mitani and Ma, 2005). The beneficial effect of Si has been demonstrated by many studies using pots, hydroponic, and field experiments. A review by Ma nicely describes how Si helps plants overcome biotic stress and abiotic stress (Ma, 2004). Plants can be supplemented with Si via a seed coating. Seed coating is one of seed dressing technique in which a thin and uniform polymer layer is deposited on the seed surface (Corlett et al., 2014). Its protective material is applied in a formulated amount and with minimal influence on the environment (Baudet and Peres, 2004). Several previous studies have reported satisfactory effects of seed coating on seed germination, seedling growth, leaf area, root and shoot growth, dry biomass and yield gain (Gevrek et al., 2012; Tavares et al., 2012).

The recognition of PGPB as potential implements for stimulating plant growth, relieving environmental stress and increasing crop yield has progressed over the past decade; today, researchers are able to reliably use them in field experiments. Among major cereals crops, rice is one of the most important commodities in the world, as it serves as food for about $50 \%$ of the world's population (Ladha et al., 1997). In South Korea, rice is a main traditional food crop. Growth attributes, nutrient content and yield enhancement of rice crops by using PGPB strains as bacterial inoculants have been reported as well as of potato, sugar beet, radish and sweet potato (Manivannan, 2011; Singh et al., 2011; Farzana et al., 2009). P. yonginensis DCY $84^{\mathrm{T}}$ showed promising plant growth promoting bacteria in vitro (Sukweenadhi et al., 2014) and showed induced systemic resistance against saline stress in planta using Arabidopsis model (Sukweenadhi et al., 2015). Silicon can alleviates the effects of other abiotic stresses including salt stress, drought stress, radiation damage, nutrient imbalance, high temperatures and freezing (Ma, 2004). Seed coating technique often employed to increase seed size, improve seed shape and texture and facilitate direct sowing. Thus, we investigated the effects of $P$. yonginensis $\mathrm{DCY} 84^{\mathrm{T}}$, combined with silicon seed coating on rice seeds to check its potential to increase rice productivity under saline stress conditions in pots, in a greenhouse and in field experiments on reclaimed tidal land. The non-protein amino acid, gamma-aminobutyric acid (GABA) rapidly accumulates in plant tissues in response to biotic and abiotic stress, and nutritional starvation stresses and regulates plant growth (Ramesh et al., 2015). The content of GABA, glutamic acid and the activity of the glutamate decarboxylase (GAD) and GABA transaminase during germination were investigated. GABA is associated with primary nitrogen and carbon metabolism and is tightly linked to the TCA cycle.

\section{Materials and methods}

\subsection{Materials}

A total of 6 different rice seed cultivars, Junam, Odae, Hiami, Samgwang, Chuchung and Koshihikari, were obtained from the Korean Rice Collection Center. The $\mathrm{SiO}_{2}$ coating method for rice seeds was conducted at Saturn Biotech in Seoul, Korea. Approximately $500 \mathrm{~g} \mathrm{SiO}_{2}$ (Zeolite) was mixed with $2 \mathrm{~kg}$ dried rice seed and rotated at $4 \mathrm{rpm}$ for $2 \mathrm{~min}$. Then, the mixture was sprayed with $300 \mathrm{ml}$ binder solution and dried for $3 \mathrm{~min}$. The coating process was repeated a second time with an additional $500 \mathrm{~g}$ dried Zeolite powder, the seeds were sprayed with $300 \mathrm{ml}$ binder solution and then they were dried for $2 \mathrm{~min}$. For the finishing step, $500 \mathrm{~g}$ dried Zeolite powder was added, the mixture was sprayed with $200 \mathrm{ml}$ sprayed binder solution and then it was dried. The ability to promote plant growth by $P$. yonginensis $\mathrm{DCY} 84^{\mathrm{T}}$, a strain recently reported by Sukweenadhi et al. (2014) was evaluated; it also can be obtained from the Korean Collection for Type Cultures (as KCTC $33428^{\mathrm{T}}$ ) and the Japan Collection of Microorganisms (as JCM 19885 ${ }^{\mathrm{T}}$ ).

\subsection{The effect of $D C Y 84^{T}$ isolates on rice seed germination}

P. yonginensis $\mathrm{DCY} 84^{\mathrm{T}}$ strain was grown at $30^{\circ} \mathrm{C}$ on Trypticase soy broth (TSB) for $16 \mathrm{~h}$. The culture broth was centrifuged at $3000 \times \mathrm{g}$ for $15 \mathrm{~min}$ and the precipitated cells were dissolved in saline water. The bacteria suspension was centrifuged again at $3000 \times g$ for $15 \mathrm{~min}$ and dissolved in saline water; centrifugation and reconstitution were repeated until the cells reached $10^{8} \mathrm{CFU} \mathrm{ml}{ }^{-1}$. Subsequently, 6 uncoated rice and coated rice seeds (Junam, Odae, Hiami, Samgwang, Chuchung and, Koshihikari) were surface sterilized using $0.02 \%$ sodium hypochlorite for $2 \mathrm{~min}$ and then rinsed using sterile distilled water. The seeds were then inoculated by soaking them in the bacteria suspension for $30 \mathrm{~min}$ (Bhatia et al., 2014). Saline water was used as a negative control treatment (Mock). The soil used in this experiment was collected from the coast of Taean, South Korea. Chemical characteristics of the soil are shown in Supplementary Table 1 . The soil was sterilized by autoclaving it at $121^{\circ} \mathrm{C}$ for $1 \mathrm{~h}$ on three consecutive days. A total of 20 rice seeds were planted for each treatment in a soil pot and 
Table 1

Effect of DCY84T and SiO2 coating during germination and early developmental seedlings (15DAS).

\begin{tabular}{|c|c|c|c|c|c|c|}
\hline \multirow[t]{2}{*}{ Treament and growth parameter } & \multicolumn{6}{|c|}{ Rice cultivar (uncoated) } \\
\hline & Junam & Hiami & Samgwang & Odae & Chuchung & Kosihikary \\
\hline \multicolumn{7}{|l|}{ Control } \\
\hline Shoot length $(\mathrm{cm})$ & $16.98 \pm 0.31$ & $11.23 \pm 0.97$ & $10.3 \pm 1.39$ & $12.31 \pm 1.53$ & $12.51 \pm 1.35$ & $11.43 \pm 2.15$ \\
\hline Roots number & $5.67 \pm 0.18$ & $4.23 \pm 0.49$ & $4.5 \pm 1.27$ & $4.37 \pm 1.24$ & $4.2 \pm 1.06$ & $4.51 \pm 1.21$ \\
\hline Roots length (cm) & $6.07 \pm 0.41$ & $3.6 \pm 0.12$ & $2.72 \pm 1.57$ & $4.57 \pm 1.54$ & $4.3 \pm 1.05$ & $3.45 \pm 1.05$ \\
\hline Fresh weight (g) & $53.93 \pm 1.86$ & $48.35 \pm 2.12$ & $49.5 \pm 2.01$ & $53.6 \pm 2.26$ & $45.45 \pm 1.71$ & $50.31 \pm 2.02$ \\
\hline Germination rate (\%) & $45 \pm 0.6$ & $36 \pm 0.25$ & $47 \pm 0.3$ & $39 \pm 1.5$ & $38 \pm 1.1$ & $38 \pm 0.7$ \\
\hline Vigor index & $1037.25 \pm 27$ & $533.88 \pm 35$ & $611.94 \pm 25$ & $658.32 \pm 38$ & $638.78 \pm 11$ & $565.44 \pm 24$ \\
\hline \multicolumn{7}{|l|}{ Paenibacillus yonginensis DCY84 ${ }^{\mathrm{T}}$} \\
\hline Shoot length $(\mathrm{cm})$ & $19.42 \pm 0.28$ & $15.31 \pm 0.52$ & $16.42 \pm 2.31$ & $13.81 \pm 2.57$ & $13.11 \pm 0.91$ & $15.24 \pm 3.61$ \\
\hline Roots number & $8.2 \pm 0.18$ & $5.2 \pm 0.16$ & $6.4 \pm 0.25$ & $5.23 \pm 0.71$ & $5.7 \pm 1.2$ & $4.1 \pm 0.91$ \\
\hline Roots length (cm) & $7.6 \pm 0.46$ & $5.45 \pm 0.23$ & $5.12 \pm 1.54$ & $7.23 \pm 1.12$ & $7.01 \pm 1.56$ & $7.5 \pm 1.36$ \\
\hline Fresh weight (g) & $59.24 \pm 1.08$ & $53.21 \pm 2.29$ & $61.74 \pm 2.87$ & $58.61 \pm 2.94$ & $66.4 \pm 2.58$ & $57.64 \pm 3.21$ \\
\hline Germination rate (\%) & $47 \pm 0.2$ & $40 \pm 2.2$ & $52 \pm 1.53$ & $53 \pm 0.5$ & $49 \pm 0.6$ & $50 \pm 0.5$ \\
\hline Vigor index & $1269.94 \pm 23$ & $830.4 \pm 22$ & $1120.08 \pm 41$ & $1115.12 \pm 32$ & $985.88 \pm 42$ & $1137.02 \pm 19$ \\
\hline \multirow[t]{2}{*}{ Treament and growth parameter } & \multicolumn{6}{|c|}{ Rice cultivar (coated) } \\
\hline & Junam & Hiami & Samgwang & Odae & Chuchung & Kosihikary \\
\hline \multicolumn{7}{|l|}{ Control } \\
\hline Shoot length $(\mathrm{cm})$ & $19.3 \pm 0.58^{* *}$ & $12.63 \pm 1.23^{*}$ & $13 \pm 0.59^{* *}$ & $11.43 \pm 0.42^{*}$ & $11.95 \pm 0.17$ & $11.38 \pm 0.65$ \\
\hline Roots number & $6.1 \pm 0.14$ & $4.33 \pm 0.46$ & $5.4 \pm 0.25$ & $4.67 \pm 0.34$ & $5.5 \pm 0.16$ & $5.75 \pm 0.11^{*}$ \\
\hline Roots length (cm) & $4.1 \pm 0.07^{* * *}$ & $3.7 \pm 0.09$ & $3.02 \pm 0.07$ & $5.27 \pm 0.55^{*}$ & $5.5 \pm 0.09$ & $3.85 \pm 0.48$ \\
\hline Fresh weight $(\mathrm{g})$ & $66.2 \pm 1.81^{* * * *}$ & $51.37 \pm 3.59^{*}$ & $53.74 \pm 1.81^{*}$ & $54.4 \pm 1.18$ & $45.85 \pm 0.57$ & $60.3 \pm 3.63^{* *}$ \\
\hline Germination rate $(\%)$ & $43 \pm 0.2^{*}$ & $38 \pm 0.3^{*}$ & $48 \pm 0.3$ & $38 \pm 0.2$ & $37 \pm 0.2$ & $40 \pm 0.3^{*}$ \\
\hline Vigor index & $1003 \pm 14^{* * *}$ & $620.67 \pm 31^{* *}$ & $768.96 \pm 17^{*}$ & $786.6 \pm 21^{*}$ & $645.65 \pm 14$ & $609 \pm 19^{*}$ \\
\hline \multicolumn{7}{|l|}{ Paenibacillus yonginensis DCY84 ${ }^{\mathrm{T}}$} \\
\hline Shoot length $(\mathrm{cm})$ & $23.3 \pm 0.42^{* * *}$ & $20.28 \pm 0.4^{* *}$ & $19.84 \pm 1.06^{* *}$ & $14.28 \pm 1.15^{*}$ & $13.96 \pm 1.35$ & $14.94 \pm 1.46$ \\
\hline Roots number & $9.0 \pm 0.32^{*}$ & $7.5 \pm 0.29^{*}$ & $7.4 \pm 0.3^{*}$ & $7 \pm 0.27^{* *}$ & $6.67 \pm 0.52^{*}$ & $5.8 \pm 0.29^{* *}$ \\
\hline Roots length $(\mathrm{cm})$ & $9.2 \pm 0.08^{* *}$ & $7.65 \pm 0.16^{* *}$ & $5.8 \pm 0.17^{*}$ & $8.67 \pm 0.51^{* *}$ & $8.53 \pm 0.45^{* *}$ & $10.2 \pm 0.73^{* *}$ \\
\hline Fresh weight $(\mathrm{g})$ & $85.7 \pm 2.25^{* * *}$ & $78.5 \pm 1.89^{* * *}$ & $73.44 \pm 3.48^{* *}$ & $64.36 \pm 3.99^{*}$ & $72.6 \pm 4.35^{* *}$ & $63.36 \pm 2.98^{* *}$ \\
\hline Germination rate (\%) & $52 \pm 0.3^{* * *}$ & $48 \pm 0.2^{* * * *}$ & $50 \pm 0.3^{*}$ & $52 \pm 0.2$ & $48 \pm 0.3$ & $52 \pm 0.2^{*}$ \\
\hline Vigor index & $1690 \pm 9^{* * *}$ & $1340.4 \pm 10^{* * *}$ & $1282 \pm 38^{* *}$ & $1192.88 \pm 49^{*}$ & $1080 \pm 52^{*}$ & $1307.28 \pm 24^{* *}$ \\
\hline
\end{tabular}

Coated seeds treatment is compared with uncoated seeds, respectively with or without bacteria treatment.

*** Statistical significance was assigned at $P<0.01$.

*** Statistical significance was assigned at $P<0.001$.

incubated under the following conditions: $16 \mathrm{~h}$ days at $28^{\circ} \mathrm{C}$ and $8 \mathrm{~h}$ nights at $20^{\circ} \mathrm{C}$ at $60 \%$ relative humidity. The rice seeds were watered daily and no additional fertilizer was used. The germination rate was recorded 5 days after sowing (DAS) while the shoot length, root length, root number, fresh weight and dry weight were recorded 15 DAS (Yoshida et al., 1976). The seedlings were dried using a $60^{\circ} \mathrm{C}$ oven for 3 days to determine the dry weight. The seedling vigor index (VI) was also calculated using the formula: $\mathrm{VI}=[$ mean root length + mean hypocotyl length $] \times \%$ germination . All of these data are shown in Table 1 . Three independent replicate experiments were performed.

\subsection{Greenhouse experiment evaluating $D C Y 84^{T}$ treatment and $\mathrm{SiO}_{2}$ coating on rice seeds under saline stress}

A concentrated suspension of $P$. yonginensis DCY84 $4^{\mathrm{T}}$ was prepared as previously described. Exactly $100 \mathrm{SiO}_{2}$-coated and 100 uncoated Junam cultivar rice seeds were co-cultured with the bacteria suspension and allowed 3 days to germinate on a petri dish $(150 \times 150 \mathrm{~mm})$ with moistened sterile tissue paper. Saline water was used as a negative control (Mock). Then, 50 well-germinated seeds were transferred to a soil pot and cultivated inside the greenhouse with $14 \mathrm{~h}$ days at $30^{\circ} \mathrm{C}$ and $10 \mathrm{~h}$ nights at $20^{\circ} \mathrm{C}, 90 \%$ relative humidity. After 1 week, 32 similar-sized rice seedlings were transferred to bigger pots. Saline stress was introduced at 15 DAS to 16 seedlings for each treatment by watering them with a $250 \mathrm{mM} \mathrm{NaCl}$ solution for 5 days. On the 5 th day, the water was changed back to normal water to allow the rice seedlings to recover. After 2 weeks of recovery (at 34 DAS), the recovery level of the rice seedlings was observed. The recovery level was judged by placing the plants into 1 of 3 categories: Good = At least 3 leaves are green; Mild $=1-2$ leaves are green; None $=$ All leaves are withered (the plant is dead). A total of 3 independent replications were performed and the data are shown in Fig. 1. A more thorough description of the salt stress treatment at the greenhouse is provided in Supplementary Fig. S1.

\subsection{Field site and climate conditions}

The field experiments were conducted on farmland near the Taean coastal area, South Korea $\left(36^{\circ} 39^{\prime} 39^{\prime \prime} \mathrm{N}, 126^{\circ} 20^{\prime} 17^{\prime \prime} \mathrm{E}\right.$, map in Supplementary Fig. S2). The landscape of the experimental area consisted of a gently sloping alluvial plain that was artificially filled with soil in 2010 (tidal land reclamation) (Choi, 2012). This region experiences warm and humid weather with an average temperature ranging between $15-25^{\circ} \mathrm{C}$ during May-October 2014 and $12-28^{\circ} \mathrm{C}$ during May-October 2015. An average annual rainfall is $800 \mathrm{~mm}$ and $600 \mathrm{~mm}$ during 2014 and 2015, respectively (http://www.accuweather.com/en/ $\mathrm{kr} /$ south-korea-weather). The monthly maximum and minimum temperatures and rainfall during the field trials is shown in Supplementary Fig. S3. The chemical characteristics of the upper soil layer $(30 \mathrm{~cm})$ were: $\mathrm{pH}$ (of 1:5 soil:water), 4.9; electrical conductance, $2.42 \mathrm{dS} \mathrm{m}^{-1}$; total organic matter, $1.10 \%$; total N, 0.54\%; available P, $40.9 \mathrm{mg} \mathrm{kg}^{-1}$ and available $\mathrm{K}, 217.6 \mathrm{mg} \mathrm{kg}^{-1}$. All of these data rep- 


\section{Recovered plants after saline stress treatment}

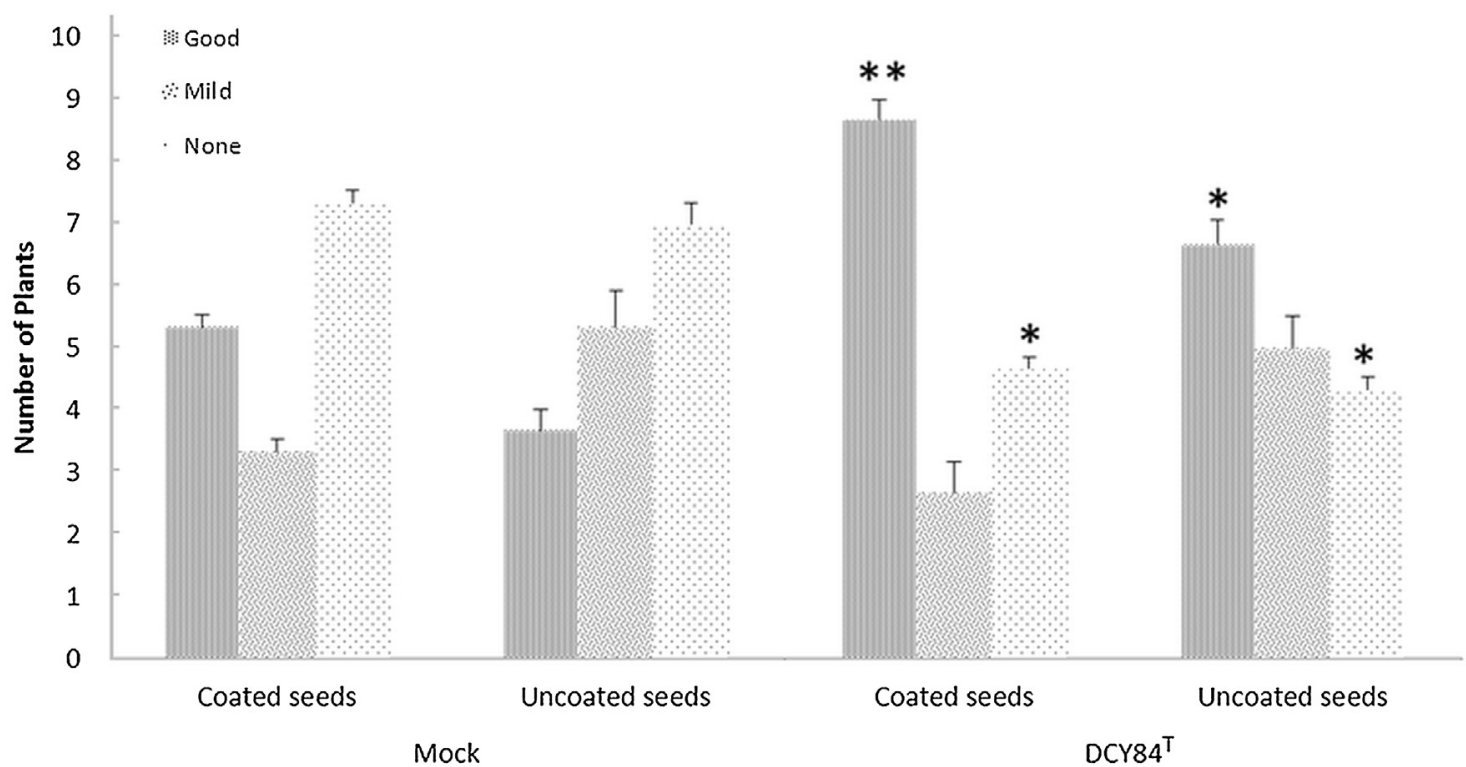

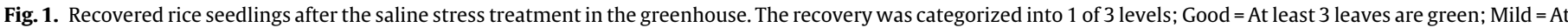
least 1 leaf is green; None = All leaves are withered (the plant is dead). Statistical significance was assigned at " " " for $P<0.05$, “*” for $P<0.01$ and “***

resent the average value from 5 representative samples as shown in Supplementary Table 1.

\subsection{Soil chemical analysis}

Soil samples were air-dried and passed through a 2-mm sieve. The chemical properties of these samples were analyzed according to the standard methods of the Rural Development Administration, Korea (RDA-Rural Development Administration and Korea, 1988). Soil $\mathrm{pH}$ and electrical conductivity (EC) were measured using a soil-to-water ratio of 1:5 with a pH meter (Thermo, Orion $900 \mathrm{~A}$ ) and an Orion 162 A conductivity meter, respectively. Soil organic matter (OM) content, phosphorus content, and the levels of available cations $\left(\mathrm{K}^{+}, \mathrm{Ca}^{2+}, \mathrm{Mg}^{2+}\right.$ and $\left.\mathrm{Na}^{+}\right)$were assessed using the Tyurin method, the Lancaster method, and the $1 \mathrm{~N}-\mathrm{NH}_{4} \mathrm{OAc}(\mathrm{pH} 7.0)$ method, respectively.

\subsection{The field test for evaluating the effects of $D C Y 84^{T}$ treatment and $\mathrm{SiO}_{2}$ coating on the growth of Junam rice cultivars}

The field test was performed between May until October 2014 and repeated on May until October 2015. The experiment used a randomized complete block (RCB) design with three replications. The size of the unit plot was $10 \mathrm{~m} \times 10 \mathrm{~m}$. In total, there was approximately $300 \mathrm{~m}^{2}$ of separated area for each treatment: Mock, DCY84 $4^{\mathrm{T}}$-treated seeds, $\mathrm{SiO}_{2}$-coated seeds and $\mathrm{DCY} 84^{\mathrm{T}}-\mathrm{SiO}_{2}$-treated seeds. Approximately $4.5 \mathrm{~kg}$ seeds were used for each treatment and spread using a spreader machine for each $100 \mathrm{~m}^{2}$ area. The farmland was regularly irrigated with water $\left(\mathrm{pH} 4.6, \mathrm{EC}=4.13 \mathrm{dS} \mathrm{m}^{-1}\right)$. The early developmental stage of seedlings was observed by sampling the rice seedlings at 30 and 60 DAS, as shown in Table 2. The shoot element analysis of 60 DAS seedlings is also provided in Table 3. Harvesting was performed at 160 DAS and yield attributes such as length of panicle, number of panicle $\mathrm{m}^{-1}$, number of spikelets panicle ${ }^{-1}$, normal spikelets panicle ${ }^{-1}$, fertility percentage (normal spikelets panicle ${ }^{-1} /$ number of spikelets panicle ${ }^{-1} \times 100 \%$ ), 1000-grain wright, grain yield and total yield are shown in Table 4. A more thorough description of the field trial is provided in Supplementary Fig. S4.

\subsection{Shoot element analysis}

For nitrogen content of the plant, sulfuric acid was added then decomposed. It was analyzed by Kjeldahl distillation (Kjeltec sytem, FOSS 8400). $1 \mathrm{~g}$ dried rice leave were treated with $10 \mathrm{ml} \mathrm{HNO}_{3}$ and decomposed by the Microwave digestion system (Mars 5, CEM) then phosphoric acid, potassium and lime were analyzed by the ICP (inductively coupled plasma analyzer, Optima 8400RL, PerkinElmer). $1 \mathrm{~g}$ sample was hydrolyzed by $3 \mathrm{ml}$ ternary solution then filtered. The remaining residue was measured for the silicate content of the rice after it was decomposed for $6 \mathrm{~h}$ in an electric furnace of $600^{\circ} \mathrm{C}$

\subsection{Rice kernel characteristics and nutrient content analysis}

Rice spikelets were hulled using a FC2 K friction machine (KETT, Japan) while milling work was performed using a MC-90A testing rice miller (Toyo Co., Tokyo, Japan) that milled spikelets to $91 \%$ of their weight ratio. Characteristics of the rice kernels were determined with a Cervitec 1625 Grain Inspector machine (FOSS, Sweden), protein content was measured with a component analyzer (Infractec 1241 Grain Analyzer) and palatability was measured with a rice taste analyzer. Rice kernel characteristics and its nutrient content for each treatment were also conducted and the results are shown in Fig. 2. Representative morphology of Junam rice cultivar grains and kernels is shown in Supplementary Fig. S5.

\subsection{Content of chlorophyll $a, b$ and carotinoid in the rice leaves}

$100 \mathrm{mg}$ of fresh rice leaf sample was powdered with liquid nitrogen and then adding $50 \mathrm{ml}$ of $80 \%$ cold acetone. Incubate in dark $4{ }^{\circ} \mathrm{C}$ for overnight, then centrifuge $2500 \mathrm{rpm} 15 \mathrm{~min}$ in $4{ }^{\circ} \mathrm{C}$. The supernatant was collected in new tube and read in different 
Table 2

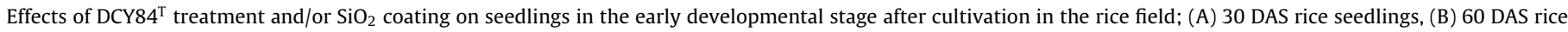
seedlings A) 30 DAS rice seedlings.

\begin{tabular}{|c|c|c|c|c|c|c|}
\hline Treatment & Fresh weight (mg) & Dry weight (mg) & Shoot dry weight (mg) & Root dry weight (mg) & Shoot length (mm) & Root length (mm) \\
\hline DCY84 ${ }^{\mathrm{T}}$ & $475 \pm 18.8^{* * *}$ & $83 \pm 5.2^{* *}$ & $45 \pm 3.2$ & $38 \pm 4.5^{* *}$ & $157 \pm 4.6^{* * *}$ & $72 \pm 5.0^{*}$ \\
\hline $\mathrm{SiO} 2$ & $585 \pm 51.5^{* * *}$ & $98 \pm 4.2^{* * *}$ & $57 \pm 2.0^{* *}$ & $41 \pm 2.7^{* * *}$ & $167 \pm 5.8^{* * *}$ & $53 \pm 5.3$ \\
\hline $\mathrm{SiO} 2+\mathrm{DCY}_{8} 4^{\mathrm{T}}$ & $518 \pm 46.3^{* * *}$ & $84 \pm 3.7^{* * *}$ & $51 \pm 4.3$ & $33 \pm 3.8^{* *}$ & $176 \pm 7.4^{* * *}$ & $59 \pm 4.9$ \\
\hline Mock & $296 \pm 29.8$ & $58 \pm 5.1$ & $42 \pm 4.6$ & $16 \pm 3.7$ & $114 \pm 6.3$ & $53 \pm 6.1$ \\
\hline \multicolumn{7}{|c|}{ (B) 60 DAS rice seedlings } \\
\hline \multicolumn{7}{|c|}{1 st year } \\
\hline DCY $84^{\mathrm{T}}$ & $4211 \pm 183.6^{* * *}$ & $1977 \pm 78.5^{* * *}$ & $1357 \pm 64.2^{* * *}$ & $620 \pm 44.2^{* * *}$ & $483 \pm 15.1^{* * *}$ & $160 \pm 4.8^{* * *}$ \\
\hline $\mathrm{SiO} 2$ & $3665 \pm 216.4^{* *}$ & $1381 \pm 65.9^{* * * *}$ & $904 \pm 48.6^{* * *}$ & $478 \pm 32.2^{* * *}$ & $489 \pm 9.6^{* * *}$ & $191 \pm 7.6^{* * *}$ \\
\hline $\mathrm{SiO} 2+\mathrm{DCY} 84^{\mathrm{T}}$ & $4957 \pm 140.4^{* * *}$ & $2097 \pm 100.6^{* * *}$ & $1435 \pm 72.7^{* * *}$ & $662 \pm 51.3^{* * *}$ & $497 \pm 11.6^{* * *}$ & $180 \pm 5.3^{* * *}$ \\
\hline Mock & $2319 \pm 315.1$ & $820 \pm 46.0$ & $596 \pm 40.2$ & $224 \pm 23.4$ & $410 \pm 10.1$ & $124 \pm 6.3$ \\
\hline \multicolumn{7}{|l|}{ 2nd year } \\
\hline DCY84 ${ }^{\mathrm{T}}$ & $4472 \pm 126.4^{* * *}$ & $1824 \pm 17.4^{* * *}$ & $1375 \pm 31.5^{* * *}$ & $449 \pm 16.8^{* * *}$ & $425 \pm 6.9^{* *}$ & $165 \pm 5.2^{* * *}$ \\
\hline $\mathrm{SiO} 2$ & $4104 \pm 158.3^{* *}$ & $1618 \pm 37.1^{* * *}$ & $1156 \pm 71.7^{* * * *}$ & $461 \pm 20.6^{* * *}$ & $429 \pm 8.2^{* * *}$ & $153 \pm 7.0^{* *}$ \\
\hline $\mathrm{SiO} 2+\mathrm{DCY} 84^{\mathrm{T}}$ & $5044 \pm 156.0^{* * *}$ & $2112 \pm 31.3^{* * *}$ & $1743 \pm 62.8^{* * *}$ & $369 \pm 12.1^{* * *}$ & $438 \pm 10.4^{* * *}$ & $168 \pm 5.5^{* * *}$ \\
\hline Mock & $3328 \pm 133.3$ & $1055 \pm 14.7$ & $843 \pm 28.9$ & $212 \pm 27.0$ & $410 \pm 5.4$ & $142 \pm 6.2$ \\
\hline
\end{tabular}

All treatment parameter is compared to Mock.

* Statistical significance was assigned at $P<0.05$.

** Statistical significance was assigned at $P<0.01$.

${ }^{* * *}$ Statistical significance was assigned at $P<0.001$.

Table 3

60 DAS shoot element analysis of $\mathrm{DCY}^{\mathrm{T}} 4^{\mathrm{T}}$ treatment and/or $\mathrm{SiO}_{2}$ coating in the Junam rice cultivar.

\begin{tabular}{|c|c|c|c|c|}
\hline \multirow[t]{2}{*}{ Element analysis } & \multicolumn{4}{|l|}{ Treatment } \\
\hline & $\mathrm{DCY} 84^{\mathrm{T}}$ & $\mathrm{SiO}_{2}$ & $\mathrm{SiO}_{2}+\mathrm{CY}_{8} 4^{\mathrm{T}}$ & Mock \\
\hline $\mathrm{Al}(\mathrm{g} / \mathrm{kg})$ & $0.47 \pm 0.007^{* *}$ & $0.43 \pm 0.020^{*}$ & $0.54 \pm 0.006^{* * *}$ & $0.35 \pm 0.016$ \\
\hline $\mathrm{Fe}(\mathrm{g} / \mathrm{kg})$ & $0.54 \pm 0.004^{* * *}$ & $0.67 \pm 0.004^{* * *}$ & $0.77 \pm 0.010^{* * *}$ & $0.29 \pm 0.012$ \\
\hline $\mathrm{P}(\mathrm{mg} / \mathrm{kg})$ & $0.87 \pm 0.005^{* * *}$ & $0.84 \pm 0.003^{* * *}$ & $0.81 \pm 0.010^{* * *}$ & $0.65 \pm 0.004$ \\
\hline $\mathrm{K}(\mathrm{cmol} / \mathrm{kg})$ & $2.66 \pm 0.109^{* *}$ & $2.05 \pm 0.034$ & $2.45 \pm 0.044^{* *}$ & $1.85 \pm 0.088$ \\
\hline $\mathrm{Ca}(\mathrm{cmol} / \mathrm{kg})$ & $0.42 \pm 0.007^{* * *}$ & $0.45 \pm 0.008^{* * *}$ & $0.46 \pm 0.009^{* * *}$ & $0.32 \pm 0.006$ \\
\hline $\mathrm{Mg}(\mathrm{cmol} / \mathrm{kg})$ & $0.62 \pm 0.012^{* * *}$ & $0.65 \pm 0.009^{* * *}$ & $0.68 \pm 0.012^{* * *}$ & $0.41 \pm 0.007$ \\
\hline $\mathrm{Na}(\mathrm{cmol} / \mathrm{kg})$ & $1.68 \pm 0.032^{*}$ & $2.02 \pm 0.017^{*}$ & $1.88 \pm 0.016$ & $1.88 \pm 0.031$ \\
\hline $\mathrm{T}-\mathrm{N}(\%)$ & $2.47 \pm 0.060^{*}$ & $1.85 \pm 0.187^{* * *}$ & $2.14 \pm 0.083$ & $1.02 \pm 0.061$ \\
\hline
\end{tabular}

* Statistical significance was assigned at $P<0.05$.

** Statistical significance was assigned at $P<0.01$.

*** Statistical significance was assigned at $P<0.001$.

Table 4

Spikelets and yield characteristics of $\mathrm{DCY} 84^{\mathrm{T}}$ treatment and/or $\mathrm{SiO}_{2}$ coating in the Junam rice cultivar.

\begin{tabular}{|c|c|c|c|c|}
\hline \multirow[t]{2}{*}{ Spikelets and yield Characteristics } & \multicolumn{4}{|l|}{ Treatment } \\
\hline & $\mathrm{SiO}_{2}+\mathrm{DCY} 84^{\mathrm{T}}$ & DCY84 ${ }^{\mathrm{T}}$ & $\mathrm{SiO}_{2}$ & Mock \\
\hline \multicolumn{5}{|l|}{ 1st year } \\
\hline Length of panicle (cm) & $18.37 \pm 3.1^{* * *}$ & $17.74 \pm 3.1^{* *}$ & $15.65 \pm 2.1^{*}$ & $16.79 \pm 2.3$ \\
\hline Number of panicle $/ \mathrm{m}^{2}$ & $105 \pm 2.7^{* *}$ & $103 \pm 2.4^{*}$ & $92 \pm 1.5$ & $91 \pm 2.2$ \\
\hline Normal spikelets/panicle & $50 \pm 2.9^{*}$ & $57 \pm 0.7^{* *}$ & $57 \pm 0.9^{* *}$ & $48 \pm 0.6$ \\
\hline Total spikelets/panicle & $114 \pm 2.9^{* * *}$ & $109 \pm 2.5^{* * *}$ & $86 \pm 1.7^{* * *}$ & $97 \pm 2.3$ \\
\hline Fertility percentage (\%) & $91.8 \pm 0.96$ & $93.7 \pm 0.47$ & $94.4 \pm 0.45$ & $94.7 \pm 0.25$ \\
\hline 1000-grain weight (gram) & $156.9 \pm 2.57^{* * *}$ & $121.8 \pm 1.29^{* * *}$ & $115.0 \pm 1.78^{*}$ & $111.0 \pm 0.16$ \\
\hline Total yield $\left(\mathrm{kg} / 100 \mathrm{~m}^{2}\right)$ & $109 \pm 0.6^{* * *}$ & $88 \pm 2.1^{* * *}$ & $75 \pm 1.0^{* * *}$ & $64 \pm 1.5$ \\
\hline Grains yield $\left(\mathrm{kg} / 100 \mathrm{~m}^{2}\right)$ & $90 \pm 0.9^{* * *}$ & $72 \pm 1.7^{* * *}$ & $60 \pm 0.9^{* *}$ & $52 \pm 1.5$ \\
\hline \multicolumn{5}{|l|}{ 2nd year } \\
\hline Length of panicle $(\mathrm{cm})$ & $18.65 \pm 5.5^{*}$ & $19.01 \pm 6.4^{* *}$ & $17.63 \pm 3.0^{*}$ & $18.10 \pm 3.9$ \\
\hline Number of panicle $/ \mathrm{m}^{2}$ & $95 \pm 1.8^{* *}$ & $97 \pm 2.5^{* *}$ & $87 \pm 1.1$ & $85 \pm 0.8$ \\
\hline Normal spikelets/panicle & $90 \pm 2.6^{* * *}$ & $87 \pm 3.1^{* * *}$ & $82 \pm 2.6^{* *}$ & $79 \pm 2.4$ \\
\hline Total spikelets/panicle & $95 \pm 3.2^{* * *}$ & $93 \pm 3.8^{* * *}$ & $82 \pm 3.1^{*}$ & $80 \pm 3.8$ \\
\hline Fertility percentage (\%) & $93.3 \pm 1.29$ & $92.5 \pm 0.34$ & $93.3 \pm 1.18$ & $95.5 \pm 2.13$ \\
\hline 1000 -grain weight (gram) & $121.6 \pm 2.15^{* *}$ & $118.2 \pm 1.38^{* *}$ & $111.3 \pm 2.08^{*}$ & $106.1 \pm 1.78$ \\
\hline Total yield $\left(\mathrm{kg} / 100 \mathrm{~m}^{2}\right)$ & $99 \pm 2.7^{* *}$ & $94 \pm 2.2^{* *}$ & $89 \pm 4.9^{*}$ & $85 \pm 2.9$ \\
\hline Grains yield $\left(\mathrm{kg} / 100 \mathrm{~m}^{2}\right)$ & $87 \pm 2.3^{* *}$ & $81 \pm 2.0^{* *}$ & $79 \pm 4.4^{*}$ & $67 \pm 2.7$ \\
\hline
\end{tabular}

${ }^{*}$ Statistical significance was assigned at $P<0.05$.

** Statistical significance was assigned at $P<0.01$.

*** Statistical significance was assigned at $P<0.001$. 
A
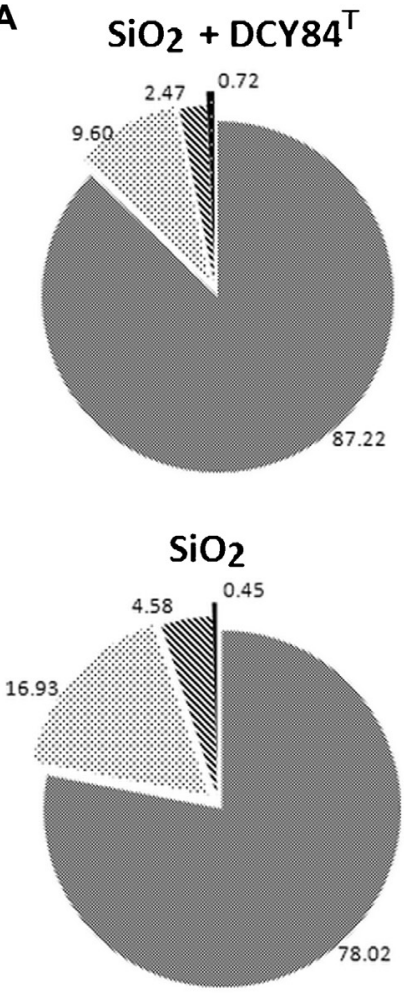

B $\quad \mathrm{SiO}_{2}+\mathrm{DCY}^{\mathrm{T}} 4^{\mathrm{T}}$
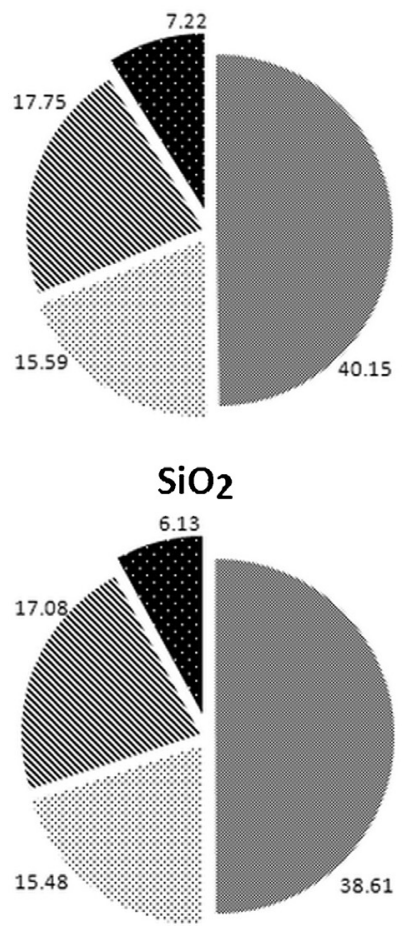

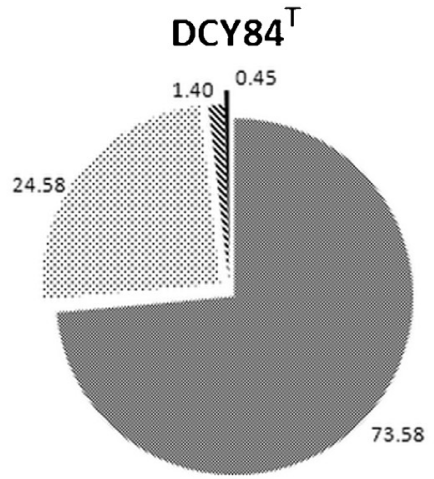

Mock

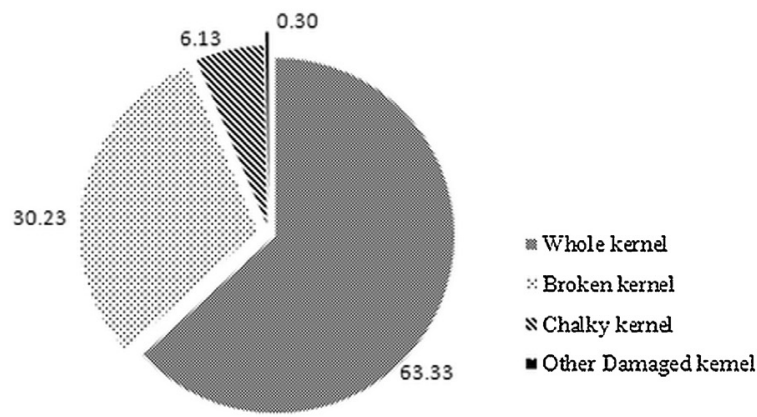

DCY84 $4^{\top}$
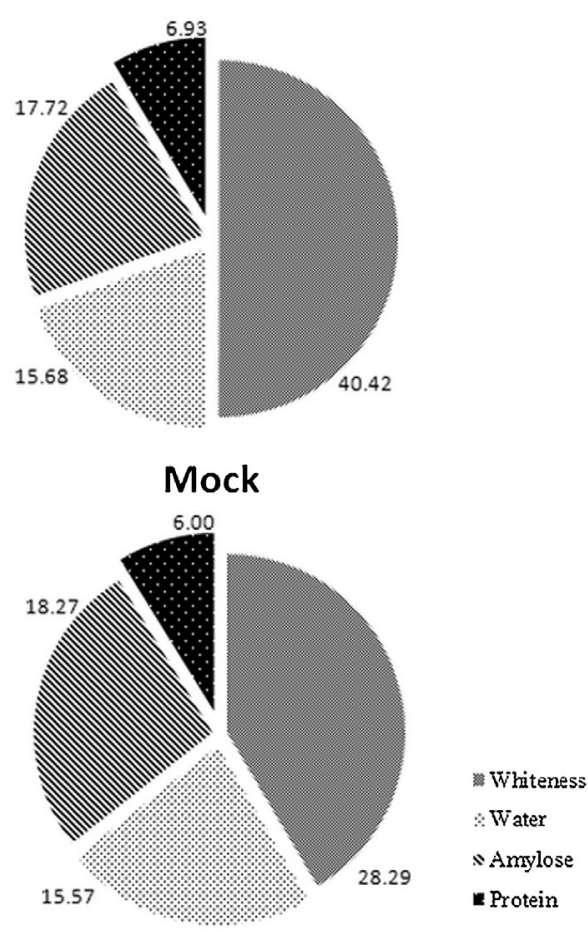

Fig. 2. A Grain characteristics and B Grain nutrient content of $\mathrm{DCY} 84^{\mathrm{T}}$ treatment and/or $\mathrm{SiO}_{2}$ coating in the Junam rice cultivar. 
absorbance 480, 645, $663 \mathrm{~nm}$. There is some formula for chlorophyll and carotenoid calculation

$$
\begin{aligned}
& \text { Chlorophyll } a=12.72 \times \text { A663-2.59 } \times \text { A645, chlorophyll } \\
& b=22.9 \times \text { A645-4.67 } \times \text { A663.Total chlorophyll }=20.31 \\
& \times \text { A645 }+8.05 \times \text { A663, carotenoid }=\mathrm{A} 480+(0.114 \\
& \times \text { A663-0.638 } \times \text { A645 })
\end{aligned}
$$

\subsection{Analysis of GABA content in the brown rice grain}

Standard GABA were purchased from Sigma (GABA 99\%, Sigma-Aldrich; USA). All solvents were HPLC grade, water, acetonitrile were purchased from Burdick \& Jackson, USA. Ammonium formate, formic acid were purchased from Sigma-Aldrich; USA. Samples were extracted by reciprocal shaker (SR-1, Taitec Co.; Japan) and centrifuged at 10,000 $\times g$ (Labogene 1736R, Korea). Shiseido Nanospace SI2 (API 3200, ABSciex, USA) were used for GABA analysis; Column was Intrada amino acid ( $3 \mathrm{~mm} \times 100 \mathrm{~mm}, 3 \mu \mathrm{m})$, mobile phase was $40 \mathrm{mM}$ ammonium formate in DW: $0.3 \%$ formic acid in ACN $(75: 25, \mathrm{v} / \mathrm{v})$. Flow rate was $0.4 \mathrm{ml} / \mathrm{min}$, injection volume was $5 \mu \mathrm{L}$. GABA was analyzed by LC/MS/MS. Ionization mode was ESI, positive ion source polarity, $1 \mathrm{mg}$ GABA was dissolved in $1 \mathrm{ml} 0.1 \mathrm{~N} \mathrm{HCl}$ and was appropriately diluted for standard solution. $3 \mathrm{~g}$ homogenized sample was mixed with $2 \%$ formic acid in $70 \%$ ethanol and homogenized for $5 \mathrm{~min}$, adjusted to $50 \mathrm{ml}$ and then homogenized again for $30 \mathrm{~min}$. After $30 \mathrm{~min}$ centrifugation at $13,000 \mathrm{rpm}$ and the supernatant was analyzed after filtration with $0.2 \mu \mathrm{m}$ syringe filter.

\section{Results}

\subsection{The effects of $\mathrm{DCY} 84^{\mathrm{T}}$ and/or $\mathrm{SiO}_{2}$ coating treatment on rice seed germination}

Seedling vigor index can be estimated by means of seedling length or seedling dry weight methods to identify favorable environment for production of good quality seeds. Since field soil was used as plant media, the vigor index calculated from the length of the plant because it will be important traits for trial on field test later. The root length is important for strengthening the plant into ground, while the shoot length is important for quickly providing the nutrient accumulation by doing photosynthesis above of water surface. Similar report used this method especially when the effect of some treatment on seedling growth was investigated (Dhanda et al., 2004; He et al., 2014; Long et al., 2008).

As shown in Table 1, almost all measures of Junam rice seedlings were increase with the $\mathrm{SiO}_{2}$ coating compared to control (without coating). A marked negative result was seen in root length, germination rate and vigor index. However, the $\mathrm{SiO}_{2}$ treatment increased shoot length $(19.3 \mathrm{~cm})$ and fresh weight $(66.2 \mathrm{~g})$ of Junam cultivar; there was also no significant difference in the case of root number. Meanwhile, $\mathrm{DCY} 84^{\mathrm{T}}$ and $\mathrm{SiO}_{2}$ coating treatment increased all seedlings growth parameter. Similar trend was showed on other cultivars regarding the increasing shoot length, root length and fresh weight at various significant levels, which resulted on increasing Vigor Index. Overall, $\mathrm{SiO}_{2}$ coating treatment mostly affects the shoots while combination of $\mathrm{DCY} 84^{\mathrm{T}}$ and $\mathrm{SiO}_{2}$ coating treatment affect both roots and shoots. For further experiments in the greenhouse and in the field, only Junam rice was used.
3.2. The greenhouse experiment of DCY84 ${ }^{T}$-treated and/or $\mathrm{SiO}_{2}$-coated rice seeds under saline stress

Pilot greenhouse tests showed that the $\mathrm{SiO}_{2}$ coating alone did not significantly affect the 34 DAS rice seedlings' recovery after saline stress $(5.3 \pm 0.19$ plants vs $3.7 \pm 0.33$ plants). Seedlings treated with $\mathrm{DCY} 84^{\mathrm{T}}$ showed a slightly better recovery than Mock seedlings, as they had a higher number of plants in the "Good" category $(6.7 \pm 0.38$ plants vs. $3.7 \pm 0.33$ plants $)$. As shown in Fig. 1 , the combination of $\mathrm{DCY}^{2} 4^{\mathrm{T}}$ and $\mathrm{SiO}_{2}$ treatments produced the highest number of "Good"-recovered plants ( $8.7 \pm 0.32$ plants), a number that is much greater than the uncoated Mock counterparts. Regardless of the $\mathrm{SiO}_{2}$ coating, the number of plants that did not recover (given a score of "None") was similar to the number of plants that received a score of "Good" when treated with DCY84 ${ }^{\mathrm{T}}$. Moreover, the number of plants that did not recover (that were categorized as "None") was lower in the DCY $84^{\mathrm{T}}$ group compared to the Mock group regardless of coating $\left(4.7 \pm 0.18\right.$ plants in the $\mathrm{DCY} 84^{\mathrm{T}}$ plus $\mathrm{SiO}_{2}$ group, $4.3 \pm 0.20$ plants in the $\mathrm{DCY} 84^{\mathrm{T}}$ group, $7.3 \pm 0.17$ plants in the $\mathrm{SiO}_{2}$ group and $7.1 \pm 0.30$ plants in the Mock group). The number of plants placed in the "Mild" recovery category was similar for all treatments.

\subsection{The effect of $D C Y 84^{T}$ treatment and/or $\mathrm{SiO}_{2}$ coating during rice field cultivation}

The early developmental period of rice seedlings is summarized in Table 2. In Table 2A, 30 DAS Junam rice cultivar seedlings exhibited greater shoot length, fresh weight and dry weight when treated with $\mathrm{DCY} 84^{\mathrm{T}}$ and/or coated with $\mathrm{SiO}_{2}$. Compared to Mock seedlings that had a shoot length of $114 \pm 6.3 \mathrm{~mm}$, the combination of $\mathrm{DCY}^{2} 4^{\mathrm{T}}$ and $\mathrm{SiO}_{2}$ treatments resulted in the tallest shoots, which were $176 \pm 7.4 \mathrm{~mm}$, followed by those with the $\mathrm{SiO}_{2}$ treatment $(167 \pm 5.8 \mathrm{~mm})$ and those with the DCY $84^{\mathrm{T}}$ treatment $(157 \pm 4.6 \mathrm{~mm})$. However, only the DCY84 ${ }^{\mathrm{T}}$ treatment led to significantly longer roots ( $72 \pm 5.0 \mathrm{~mm}$ vs. Mock, $53 \pm 6.1 \mathrm{~mm}$ ). Both the $\mathrm{DCY} 84^{\mathrm{T}}$ and/or $\mathrm{SiO}_{2}$ treatment had a heavier fresh weight (475 $\pm 18.8-585 \pm 51.5 \mathrm{mg})$ compared to the Mock treatment $(296 \pm 29.8 \mathrm{mg})$ and a heavier dry weight $(83 \pm 5.2-98 \pm 4.2 \mathrm{mg})$ compared to the Mock treatment $(58 \pm 5.1 \mathrm{mg})$. When focusing on dry weight, $\mathrm{DCY} 84^{\mathrm{T}}$ and/or $\mathrm{SiO}_{2}$ treatment groups all resulted in a heavier root dry weight, but only the $\mathrm{SiO}_{2}$ treatment group showed heavier shoot dry weights $(57 \pm 2.03 \mathrm{mg})$ compared to the Mock group $(42.3 \pm 4.62 \mathrm{mg})$. All in all, the $\mathrm{SiO}_{2}$ coating without $\mathrm{DCY} 84^{\mathrm{T}}$ led to the most favorable 30 DAS rice seedling parameters. The measurement was done for the first year field trial.

As shown in Table $2 \mathrm{~B}, \mathrm{DCY} 84^{\mathrm{T}}$ treatment and/or $\mathrm{SiO}_{2}$ coating significantly improved the growth of the seedlings in regard to many metrics compared to the Mock treatment group. For example, shoots ( $483 \pm 15.1-497 \pm 11.6 \mathrm{~mm}$ vs. Mock, $410 \pm 10.1 \mathrm{~mm})$ and roots $(160 \pm 4.8-191 \pm 7.6 \mathrm{~mm}$ vs. Mock, $124 \pm 6.3 \mathrm{~mm})$ were longer than those in the Mock treatment group. The combination of $\mathrm{DCY} 84^{\mathrm{T}}$ and $\mathrm{SiO}_{2}$ treatments resulted in the heaviest fresh $(4957 \pm 140.1 \mathrm{mg}$ vs. $2319 \pm 315.1 \mathrm{mg}$ for Mock) and dry weight $(2097 \pm 100.6 \mathrm{mg}$ vs. $820 \pm 46.0 \mathrm{mg}$ for Mock). Moreover, the heaviest shoot and root dry weights were observed with both $\mathrm{DCY} 84^{\mathrm{T}}$ treatment and $\mathrm{SiO}_{2}$ coating; dry shoots and dry roots were $1435 \pm 72.7 \mathrm{mg}$ (vs. Mock, $596 \pm 40.2 \mathrm{mg}$ ) and $662 \pm 51.3 \mathrm{mg}$ (vs. Mock, $224 \pm 23.4 \mathrm{mg}$ ), respectively. These significant results also showed consistently at second year field trial, whereas the combination of $\mathrm{DCY} 84^{\mathrm{T}}$ and $\mathrm{SiO}_{2}$ treatments resulted in the heaviest fresh $(5044 \pm 156 \mathrm{mg}$ vs. $3328 \pm 133 \mathrm{mg}$ for Mock) and dry weight ( $2112 \pm 31.3 \mathrm{mg}$ vs. $1055 \pm 14.7 \mathrm{mg}$ for Mock), also significantly longer shoots $(425 \pm 6.9-438 \pm 10.4 \mathrm{~mm}$ vs. Mock, $410 \pm 5.4 \mathrm{~mm})$ and roots $(153 \pm 7.0-168 \pm 5.5 \mathrm{~mm}$ vs. 
Mock, $142 \pm 6.2 \mathrm{~mm}$ ) consistently showed on treatment group. Again, $\mathrm{DCY} 84^{\mathrm{T}}$ treatment and $\mathrm{SiO}_{2}$ coating combination treatment provide heaviest shoot and root dry weights which was $1743 \pm 62.8 \mathrm{mg}$ (vs. Mock, $843 \pm 28.9 \mathrm{mg}$ ) and $369 \pm 12.1 \mathrm{mg}$ (vs. Mock, $212 \pm 27.0 \mathrm{mg}$ ), respectively. Thus, the combination of DCY84 ${ }^{\mathrm{T}}$ and $\mathrm{SiO}_{2}$ treatments resulted in the most favorable characteristics of 60 DAS rice seedlings.

\subsection{Shoot element analysis}

As shown in Table 3, plants treated with $\mathrm{DCY}^{\mathrm{T}}{ }^{\mathrm{T}}$ had the most phosphate $[\mathrm{P}] \quad\left(0.87 \pm 0.005 \mathrm{mg} \mathrm{kg}^{-1}\right)$, potassium $[\mathrm{K}]\left(2.66 \pm 0.109 \mathrm{cmol} \mathrm{kg}^{-1}\right)$ and total nitrogen [T-N] $(2.47 \pm 0.06 \%)$. Plants treated with $\mathrm{SiO}_{2}$ had the most sodium [Na] $\left(2.02 \pm 0.017 \mathrm{cmol} \mathrm{kg}^{-1}\right)$. Furthermore, plants treated with both $\mathrm{DCY}^{\mathrm{T}}{ }^{\mathrm{T}}$ and $\mathrm{SiO}_{2}$ had the most aluminum [Al] $\left(0.54 \pm 0.006 \mathrm{~g} \mathrm{~kg}^{-1}\right)$, iron $[\mathrm{Fe}] \quad\left(0.77 \pm 0.010 \mathrm{~g} \mathrm{~kg}^{-1}\right)$, calcium [Ca] $\left(0.46 \pm 0.009 \mathrm{cmol} \mathrm{kg}^{-1}\right)$ and magnesium $[\mathrm{Mg}]$ $\left(0.68 \pm 0.012 \mathrm{cmol} \mathrm{kg}^{-1}\right)$

\subsection{Yield characteristics}

Surprisingly, $\mathrm{DCY}^{\mathrm{T}} 4^{\mathrm{T}}$ and/or $\mathrm{SiO}_{2}$ did not significantly affect the fertility percentage (Table 4). However, DCY84 ${ }^{\mathrm{T}}$ plus $\mathrm{SiO}_{2}$ did result in a higher number of spikelets per panicle (2014: $114 \pm 2.9$ vs. Mock, $97 \pm 2.3 ; 2015$ : $90 \pm 2.6$ vs. Mock, $79 \pm 2.4$ ) as shown in Table $4 . \mathrm{SiO}_{2}$ treatment resulted in the lowest number of spikelets per panicle at first trial $(81 \pm 1.5)$ and at second trial observation $(82 \pm 3.1$ vs. Mock, $80 \pm 3.8)$. Furthermore, $\mathrm{SiO}_{2}$ treatment also resulted in the shortest panicle, which was $16 \pm 2.1 \mathrm{~cm}$ at 2014 trial and $18 \pm 3.0 \mathrm{~cm}$ at 2015 trial, while the longest panicle was observed with the $\mathrm{SiO}_{2}$ and $\mathrm{DCY} 84^{\mathrm{T}}$ treatment $(18 \pm 3.1 \mathrm{~cm}$ vs. Mock, $17 \pm 2.3 \mathrm{~cm}$ ). 1000-grain weight revealed either DCY $84^{\mathrm{T}}$ with $\mathrm{SiO}_{2}$ (2014: $\left.156.9 \pm 2.57 ; 2015: 121.6 \pm 2.15\right)$ or without $\mathrm{SiO}_{2}$ (2014: $121.8 \pm 1.29$; 2015: $118.2 \pm 1.38$ ) gave significantly higher mass. SiO2Treatment with $\mathrm{DCY} 84^{\mathrm{T}}$ and/or $\mathrm{SiO}_{2}$ gave a greater grain yield and a greater total yield; $\mathrm{DCY} 84^{\mathrm{T}}$ plus $\mathrm{SiO}_{2}$ treatment yielded the highest mass, $90 \mathrm{~kg}$ for grain yield (vs. Mock, $52 \mathrm{~kg}$ ) and $109 \mathrm{~kg}$ for total yield (vs. Mock, $64 \mathrm{~kg}$ ), each from $100 \mathrm{~m}^{2}$ harvested area. Second trial at 2015 resulted consistently, with $99 \mathrm{~kg}$ of total yield and $87 \mathrm{~kg}$ of grain yield for $\mathrm{DCY} 84^{\mathrm{T}}$ and $/$ or $\mathrm{SiO}_{2}$ treatment (vs. Mock, $85 \mathrm{~kg}$ and $67 \mathrm{~kg}$, respectively). Morphology of normal and abnormal spikelet can be seen in Supplementary Fig. S5.

\subsection{Rice kernel characteristics and grain nutrient analysis}

As shown in Fig. 2A, the combination of $\mathrm{DCY} 84^{\mathrm{T}}$ and $\mathrm{SiO}_{2}$ treatments resulted in the highest whole kernel percentage $(87.2 \pm 0.57 \%)$, followed by $\mathrm{SiO}_{2}$ treatment $(78.0 \pm 0.81 \%)$ and DCY $84^{\mathrm{T}}$ treatment $(73.6 \pm 2.41 \%)$. As a consequence of having lowest whole kernel percentage $(63.3 \pm 0.38 \%)$, seedlings in the Mock treatment group had the highest broken kernel percentage, which was $35.2 \pm 0.45 \%$. Remarkably, plants in the $\mathrm{SiO}_{2}$ treatment group had $4.6 \pm 0.24 \%$ chalky kernels and the highest protein percentage $(7.2 \pm 0.64 \%)$, whereas those in the Mock treatment group had only $1.1 \pm 0.03 \%$ chalky kernels and lowest protein percentage $(6.0 \pm 0.08 \%)$. Nutrient content analysis showed distinct results for each treatment (Fig. 2B). Grains in the Mock treatment group scored the poorest in all parameters except amylose percentage, for which it was the highest at $18.3 \pm 0.05 \%$.

\subsection{Content of Chlorophyll $a, b$ and carotinoid in the rice leave}

The content of chlorophyll a, b and carotinoid in the rice leaves which were treated with silica and DCY $84^{\mathrm{T}}$ has increased more than the mock without treatment.

\subsection{Analysis of GABA content in brown rice grain}

The silica and PGPR treated rice has essential amino acid more higher than the Mock (control) that was not treated. Major amino acid in the rice are composed of glutamate, aspartic acid, leucine, and valine. GABA content was detected by LC/MS/MS, silica and microbial dressing on the sprouted rice show higher GABA content than mock. Gene expression via RNA sequencing, future verification are required to be confirmed. Based on the genome analysis result of the strain $\mathrm{DCY} 84^{\mathrm{T}}$ that several sets of glutamate decarboxylase, malate transporter gene which involved in GABA production pathway were presented (data not shown). Each samples were treated by triplicate. After harvest, the GABA content of brown rice grain showed a 1.9-fold increase (field trial in 2014), 1.5 fold increase (2015) compared to mock grain, respectively.

\section{Discussion}

Agriculture is extremely susceptible to global climate change. Temperature and precipitation disturbances have limited not only the farming areas that are possible for agriculture, but also its crop growth and yields. Among the several different techniques that contribute to increasing rice crop productivity, soil fertilization with nutrients is paramount and silicon $(\mathrm{Si})$, specifically, is one of the most important nutrients for rice. It helps the plants overcome multiple stresses including biotic and abiotic stress (Mitani and $\mathrm{Ma}, 2005$ ). Seeds can be supplemented with silicon through seed coating, a common practice especially for the seeds of horticulture plants, forest plants and ornamentals. This advanced technology allows the application of a combination of nutrients, fungicides, insecticides, herbicides and beneficial microorganisms to the seeds (Corlett et al., 2014).

Microbiological communities in the soil or rhizosphere contribute to plant growth by recycling nutrients and making them available to the plant, increasing root health through competition with root pathogens or enhancing nutrient uptake (Weller et al., 2002). Among them, a group of beneficial plant bacteria referred to as plant growth-promoting bacteria (PGPB) are beneficial to plants via nutrient acquisition (Ladha and Reddy, 2003), biocontrol (Walsh et al., 2001), production of plant hormone-like compounds, reduction of the plant ethylene level (Glick, 1995) and induction of systemic resistance (van Loon et al., 1998). P. yonginensis DCY84 ${ }^{\mathrm{T}}$, a promising PGPB previously described by Sukweenadhi et al. (2014), has been found to have the ability to produce indole acetic acid, produce siderophores, solubilize phosphate and also give the Arabidopsis plant resistance against drought, saline and aluminum stress (Sukweenadhi et al., 2015).

Junam-byeo (Oryza sativa L. cv. Junam) was used as the main experimental cultivar in this study. It is the most widely cultivated rice strain in Korea and it was registered as a new japonica rice cultivar in 2006 (Kim and You, 2010). In the soil pot test, all seeds had a germination rate of not more than $55 \%$ regardless of the treatment (Table 1). With the EC value around $2.42 \pm 0.257 \mathrm{dS} \mathrm{m}^{-1}$ (Supplementary Table S1), this soil condition provided enough salinity stress to inhibit the seedlings' growth as previously described on a rice crop field in California with an EC value range of $0.5-3.0 \mathrm{dS} \mathrm{m}^{-1}$ (Scardaci et al., 1996). As a salt-sensitive crop, young rice seedlings are at a stage that is particularly sensitive to salinity (Lutts et al., 1995). Therefore, the early developmental stage of rice seedlings was assessed to test the effectiveness of $\mathrm{DCY} 84^{\mathrm{T}}$ and/or $\mathrm{SiO}_{2}$ treatments on rice growth under saline stress. We observed in vitro that $\mathrm{SiO}_{2}$-coated seeds germinated later (3-4 days) while seeds in the Mock group took only $1-2$ days (data not shown). Not only germination rate, coating treatment also significantly reduced root length but it increased the shoot length. Although several growth param- 
eters were measured, the vigor index is an important parameter because it reflects the overall health of the seedling and the productivity of the plant. A higher vigor index predicts a better yield from the plant, since the young seedlings grow better on saline field. Seeds treated with the $\mathrm{SiO}_{2}$ coating had an overall lower vigor index compared to the combination of $\mathrm{DCY}^{\mathrm{T}} 4^{\mathrm{T}}$ and $\mathrm{SiO}_{2}$. This result corroborates another related study in that Pseudomonas pseudoalcaligenes and Bacillus pumilus promoted rice growth under saline conditions (Jha et al., 2011). Longer shoots and roots of $\mathrm{SiO}_{2}$-treated seeds also confirmed previous studies that reported satisfactory effects of a seed coating on root and shoot growth (Tavares et al., 2012).

The pilot experiment at the greenhouse was performed by introducing salinity stress $(250 \mathrm{mM} \mathrm{NaCl})$ to young seedlings (15 DAS), not seeds. The seedling stage is one of the most sensitive stages to salt stress in rice, and a trial of salt tolerance during this stage can probably provide insight into the field test results. During the stress period, all treatments exhibited similar symptoms, either pale-green leaves or withered leaves. However, after a recovery period, seedlings in the $\mathrm{DCY} 84^{\mathrm{T}}$ plus $\mathrm{SiO}_{2}$ treatment group recovered significantly better than those in the Mock group while the $\mathrm{SiO}_{2}$ coating itself did not have a strong influence on the recovery level (Fig. 1). It seems that pre-inoculation with $\mathrm{DCY} 84^{\mathrm{T}}$ triggered resistance against salinity stress in the rice. This result corresponds with a previous study in which $\mathrm{DCY} 84^{\mathrm{T}}$ pre-inoculation promoted plant tolerance against salt on Arabidopsis thaliana (Sukweenadhi et al., 2015). Following these greenhouse results, we performed a similar experiment in a rice field on a reclaimed tidal land. As one of South Korea's efforts to expand farming areas, an estuarine tidal flat was developed on the coast of the West Sea in South Korea. Around 30\% of the land has been set aside for agriculture. Only $17 \%$ of these lands have a salinity level that is acceptable for crop cultivation and the remaining $83 \%$ of the land has been deemed unsuitable for crop growth due to high salt levels. This land also has several other drawbacks such as limited macroand micronutrients, restricted organic matter and physical and chemical properties that do not promote a good crop yield (Kim et al., 2014). Thus, these areas will require an integrated management strategy. Biotechnology provides promising solutions to improve not only the quality of crop itself, but also the interaction of the roots with soil-dwelling microbial partners. Commercial applications of PGPB are being tested and are frequently successful (Farzana et al., 2009). As observed on the seedlings at 60 DAS (Table 2), both $\mathrm{DCY} 84^{\mathrm{T}}$ plus $\mathrm{SiO}_{2}$ treatments resulted in the best growth parameters, followed by the $\mathrm{DCY} 84^{\mathrm{T}}$ treatment. This result corroborates a previous report of Methylobacterium oryzae CBMB20 and Brevibacterium iodinum RS16 on sorghum and maize on reclaimed land (Kim, 2014). However, at an earlier stage (30 DAS), the $\mathrm{SiO}_{2}$ treatment led to greater shoot and root dry weights, demonstrating the importance of silicon during the germination stage of rice in saline soil. Rice plants usually take up Si from soil at levels several fold greater than essential macronutrients such as $\mathrm{N}, \mathrm{P}$ and $\mathrm{K}$. Therefore, rice is a specific silica-accumulator among higher plants. The $\mathrm{Si}$ in rice enhances resistance to biotic and abiotic stresses (Tsujimoto et al., 2014). Thus, a $\mathrm{SiO}_{2}$ coating might be useful to help young seedlings (around 30 DAS) grow under saline conditions. Under salinity stress, salt injury symptoms were perceptible including leaf drying and burning; severely stunted plant growth was seen in the Mock rice plants, but not in the treated rice. As previously reported by Sarangi et al. (2015), at a high seed density $\left(40 \mathrm{~g} \cdot \mathrm{m}^{-2}\right)$, the average seedling shoot length was $533 \mathrm{~mm}$ and the average seedling root length was $139 \mathrm{~mm}$ for 40 DAS seedlings, which was lower than the results with a low seed den$\operatorname{sity}\left(25 \mathrm{~g} \mathrm{~m}^{-2}\right)$. Meanwhile, in this experiment, the average DCY84 ${ }^{\mathrm{T}}$ and/or $\mathrm{SiO}_{2}$-treated seedlings' shoot length and root length were 483-497 $\mathrm{mm}$ and $160-191 \mathrm{~mm}$, respectively (measured in 60 DAS seedlings). Thus, the $\mathrm{DCY} 4^{\mathrm{T}}$ and/or $\mathrm{SiO}_{2}$ treatments might have helped the seedlings overcome the high density of the seedlings $\left(45 \mathrm{~g} \mathrm{~m}^{-2}\right)$. Meanwhile, previously, co-inoculation of PGPB during the early developmental stage on plants grown in Saemangeum reclaimed soil showed that plant growth-promoting $B$. iodinum RS16 and M. oryzae CBMB20 increased plant height, dry biomass accumulation and macro-nutrient accumulation of maize and a sorghum-sudangrass hybrid. Macronutrient accumulation ( $\mathrm{P}, \mathrm{K}$, $\mathrm{Ca}$ and $\mathrm{Mg}$ ) was higher with $M$. oryzae CBMB20 treatment compared to the non-inoculated treatment, while B. iodinum RS16 treatment increased $\mathrm{N}, \mathrm{Ca}$ and $\mathrm{Mg}$ accumulation compared to the non-inoculated treatment (Kim et al., 2014). Another report found that inoculation with Actinomycetes $\mathrm{NB}_{1}$, AVermi7, YB6y and $\mathrm{NB}_{3}$ in combination with a full rate of fertilization significantly increased P uptake by 80 to $136 \%$ over the non-inoculated control (Cruz et al., 2014). This pattern of nutrient uptake and accumulation was also observed with $\mathrm{DCY} 84^{\mathrm{T}}$ and/or $\mathrm{SiO}_{2}$ treatment on the Junam rice cultivar after 60 days on reclaimed tidal land (Table 3 ). Remarkably, we observed that DCY $84^{\mathrm{T}}$ treatment increased P accumulation by $34 \%$, available $\mathrm{K}$ by $44 \%$ and 2.4 -fold higher total $\mathrm{N}$ content compared to the Mock group while $\mathrm{DCY} 84^{\mathrm{T}}$ plus $\mathrm{SiO}_{2}$ treatments showed the highest amounts of $\mathrm{Al}, \mathrm{Fe}, \mathrm{Ca}$ and $\mathrm{Mg}$ (54\%, $169 \%, 42 \%$ and $67 \%$ higher, respectively, compared to the Mock group). Previous report on saline-stressed barley, silicon found to enhance salt tolerance attributed to selective uptake and transport of potassium and sodium by reducing sodium but increasing potassium concentrations (Liang, 1999). Meanwhile, Gong et al. (2006) reported silicon deposition in the exodermis and endodermis reduced sodium uptake in rice (Oryza sativa L.) seedlings under $\mathrm{NaCl}$ stress through a reduction in byplass flow. However, at 60 DAS Junam rice seedlings, either sodium and potassium concentration were found to be higher than Mock. It seems that the Si-coating treated seeds have different mechanism of alleviating saline stress compared to Si-giving seedlings. Further study is needed to confirm this prejudice.

Plants treated with both $\mathrm{DCY} 84^{\mathrm{T}}$ and $\mathrm{SiO}_{2}$ had the lowest normal grain percentage, but they had the highest number of grains/panicles (Table 4). This result confirmed previous silicon fertilization treatment of upland rice, which reduced the number of blank (abnormal) spikelets per panicles and increased grain mass, but did not affect grain productivity (Mauad et al., 2003). DCY84 ${ }^{\mathrm{T}}$ and/or $\mathrm{SiO}_{2}$ treatments gave a higher grain yield and total yield compared to Mock crops, and treatment with $\mathrm{DCY} 84^{\mathrm{T}}$ plus $\mathrm{SiO}_{2}$ yielded the highest mass (in average grain yield was $44 \%$ greater and total yield was $43 \%$ greater). Das and Saha (2005) reported that PGPB inoculation with non-symbiotic $\mathrm{N}_{2}$ fixing bacteria Azotobacter (strain DS3) and Azospirillum (strain DM10) significantly increased growth and yield (23.7\%) of rice. Kernel analysis showed that $\mathrm{DCY} 84^{\mathrm{T}}$ and/or $\mathrm{SiO}_{2}$ treatment significantly increased the whole kernel percentage and decreased the broken kernel percentage. With a full rate of fertilization, inoculation with $\mathrm{NB}_{3}$ and AVermi7 significantly increased grain yield and total yield by $62 \%$ and $48 \%$, respectively, relative to non-inoculated treatment. The significant increase in grain yield by $\mathrm{NB}_{3}$ and AVermi7 demonstrated the potential of these Actinomycetes as plant growth-promoting inoculants for upland rice (Cruz et al., 2014).

In case of grains quality, $\mathrm{DCY} 84^{\mathrm{T}}$ and/or $\mathrm{SiO}_{2}$ treatment highly increased the whole kernel percentage. Thus, lower its broken kernel percentage to $9.60-24.58 \%$ (Fig. 2A). Broken rice is generally at only 30 to $50 \%$ of whole grain and it considerably lower commercial value than whole, unbroken kernels; therefore, farmer strive to produce rice with the least amount of broken rice (Mutters, 1998). Grain formation process play important roles in this and previous report found that salt stress during reproduction stage can disrupt this process (Moradi et al., 2003). Lower broken ker- 


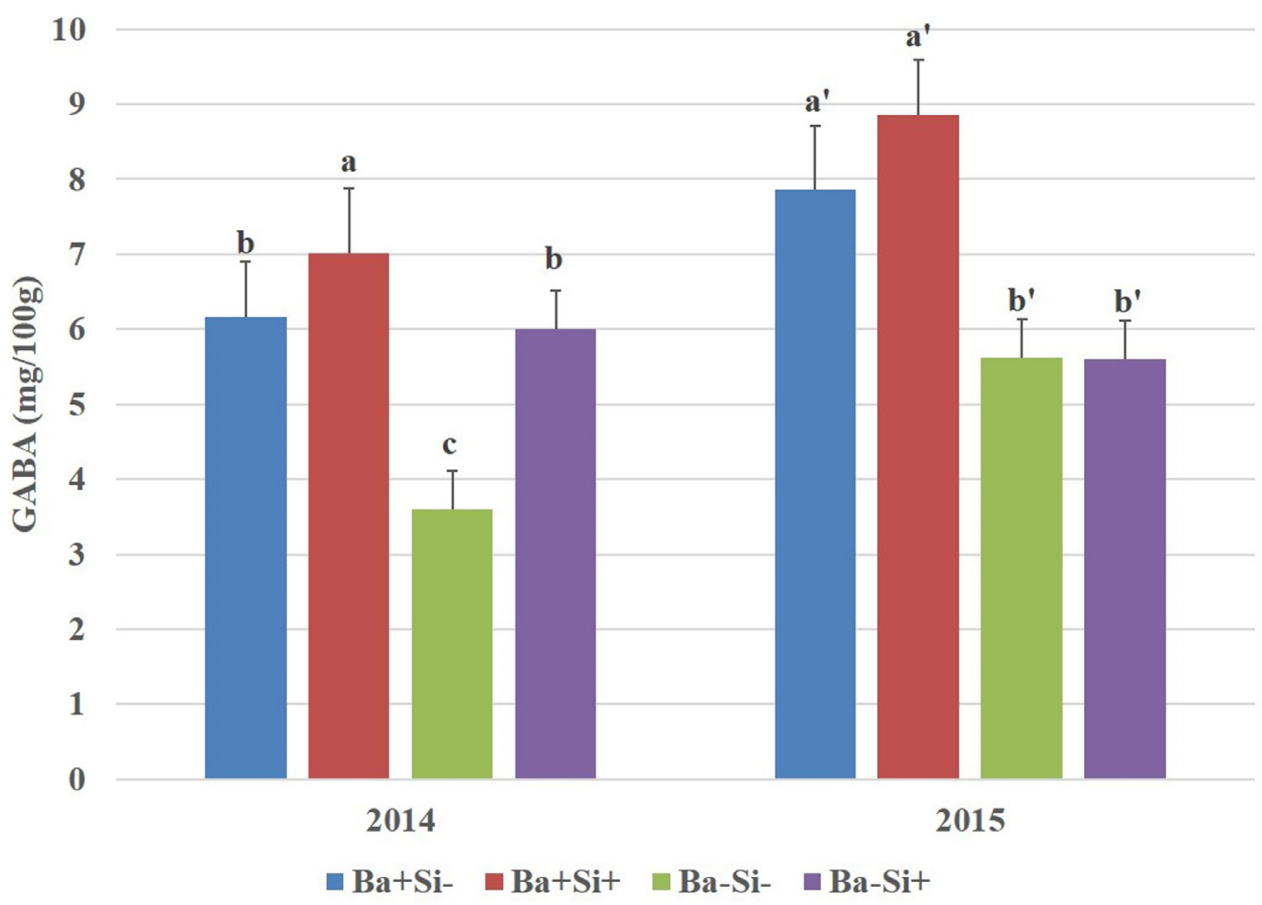

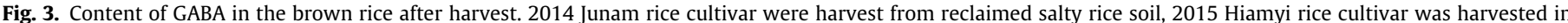

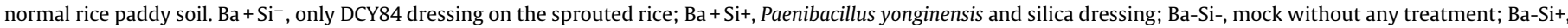
only silica dressing. The differences are highly significant $(\mathrm{a}, p<0.001),\left(\mathrm{a}^{\prime}, p<0.01\right)$.

nel indicated that $\mathrm{DCY} 84^{\mathrm{T}}$ and/or $\mathrm{SiO}_{2}$ treatment can alleviate the salt stress interference during the grain filling process. Meanwhile, chalkiness percentage of all treatment seems to be correlated with its total $\mathrm{N}$ content in which higher $\mathrm{N}$ content reduce the percentage of chalky kernels on yield. Qiao et al. (2011) reported that $\mathrm{N}$ fertilizer had a favorable effect in decreasing the ratio of chalky grains. It is well-known that the formation of chalkiness is associated with an insufficient substrate supply during the arrangement, size and shape of starch granule on the developing endosperm (Lisle et al., 2000). Based on amylose content, milled rice is classified in "amylose group" such as: waxy (1-2\% amylose), very low amylose content (10-20\% amylose), intermediate amylose content (20-25\% amylose), high amylose content (25-33\% amylose) (IRRIInternational Rice Research Institute, 2004). Belong to Japonica, amylose content of Junam cultivar kernels were similar each other (range between 17.08-18.27\%) regardless its treatment (Fig. 2B). This result confirms Junam cultivar as very low amylose content group, which commonly consumed in Northeast Asia, where a more cohesive cooked grain is often preferred; they are characteristic of the temperate Japonica variety groups that predominate in this region (Juliano and Villareal 1993). However, DCY84 ${ }^{\mathrm{T}}$ plus $\mathrm{SiO}_{2}$ treatment resulted on highest protein content, which was above $7 \%$. Generally, the taste of rice is determined by protein and amylose content. Rice with a good taste has a protein content under $7 \%$ and a water content between $15.5 \%$ and $16.5 \%$. When rice is cooked, rice with a higher protein content is more compact, less elastic and less viscous (Yun et al., 2014). It already known that the protein content of milled rice is low in comparison with other cereals, although the whole rice grain protein content ranged from 7.0 to $10.8 \%$ of which $70-80 \%$ is in the glutelin. Commonly eaten rices generally contain about $7 \%$ protein and do not fluctuate widely form this level, protein content is not considered an important indicator of quality (Hamaker and Griffin, 1993). Meanwhile, there were no significant differences in the water content of the rice in any of the treatment groups (15.4-15.7\%). Our findings show for the first time that GABA seems to have a protective role in silica and Paenibacillus strain DCY84 treated rice in reclaimed salty soil Fig. 3.

\section{Conclusions}

This field study provides encouraging results and a basis for future research. The overall results show that $\mathrm{DCY} 84^{\mathrm{T}}$ coinoculation and/or $\mathrm{SiO}_{2}$ coating of seeds can be useful methods to promote the growth of rice under saline stress conditions. It increased the seed germination and seedling vigor index during saline stress based on pot test and significantly help the seedlings growth on reclaimed tidal land. Thus, the total yield also significantly increased even though the cultivation was done under saline condition. The seed dressing effect seems not too strong for individual bacteria $\left(\mathrm{DCY} 84^{\mathrm{T}}\right)$ or coating $\left(\mathrm{SiO}_{2}\right)$ treatment, but stronger on combination of both treatment. The bacterial treatment might affected most on root system while Silicon treatment might affected on shoot system. It may function by increasing the endogenous levels of GABA to improve root growth and by decreasing the salt stress. Further, transcriptomic with metabolomics approach can be done to reveal the role of bacteria and silicon. Optimization the protocol for the use of $\mathrm{DCY} 84^{\mathrm{T}}$ (or other PGPB) and $\mathrm{SiO}_{2}$ seed coating with technical formulation trials can be useful for further improved crop quality. Indeed, the results of this study can be applied to other reclaimed tidal lands of South Korea or other areas in coastal states of South Korea that have similar ecologies.

\section{Acknowledgments}

This study was supported by the Business for Cooperative R\&D between Industry, Academy, and Research Institute funded by the Korea Small and Medium Business Administration in 2014 (Grant No. C0214183), Republic of Korea. We also thanks to Saturn Biotech for their corporation. 


\section{Appendix A. Supplementary data}

Supplementary data associated with this article can be found, in the online version, at http://dx.doi.org/10.1016/j.fcr.2016.01.005.

\section{References}

Ahmad, F., Ahmad, I., Khan, M.S., 2008. Screening of free-living rhizospheric bacteria for their multiple plant growth promoting activities. Microbiol. Res. 163, 173-181.

Bano, A., Fatima, M., 2009. Salt tolerance in Zea mays (L.) following inoculation with Rhizobium and Pseudomonas. Biol. Fert. Soils 45, 405-413.

Bashan, Y., Holguin, G., de-Bashan, L.E., 2004. Azospirillum-plant relationships, physiological, molecular, agricultural, and environmental advances (1997-2003). Can. J. Microbiol. 50, 521-577.

Baudet, L.M., Peres, W., 2004. Seed coating. Seed News 8, 20-23.

Berg, G., 2009. Plant-microbe interactions promoting plant growth and health: perspectives for controlled use of microorganisms in agriculture. Appl. Microbiol. Biotechnol. 84, 11-18

Bhatia, P., Sharma, P., Khosla, B., Machiavelli, 2014. Characterization for plant growth promoting rhizobacteria (PGPR) towards rice (Oryza sativa) seedling germination and growth. Ann. Biol. 30 (4), 567-573.

Cho, J.Y., Son, J.G., Choi, J.K., Song, C.H., Chung, B.Y., 2008. Surface and subsurface losses of $\mathrm{N}$ and $\mathrm{P}$ from salt-affected rice paddy fields of Saemangeum reclaimed land in South Korea. Paddy Water Environ. 6 (2), 211-219.

Choi, W., 2012. Geographical research trend and task on formation of rura settlement in Taean Peninsula Region. Geog. J. Korea 1 (2), 247-265.

Corlett, F.M., Rufino, C.D.A., Vieira, J.F., Tavares, L.C., Tunes, L.V., Barros, A.C., 2014 The influence of seed coating on the vigor and early seedling growth of barley. Cien. Inv. Agr. 41 (1), 129-136.

Cruz, J.A., Lantican, N.B., Delfin, E.F., Paterno, E.S., 2014. Enhancement of growth and yield of upland rice (Oryza sativa L.) var. NSIC Rc 192 by actinomycetes. J. Agric. Sci. Technol. 10 (4), 875-883.

Das, A.C., Saha, D., 2005. Non symbiotic nitrogen fixing bacteria influencing mineral and hydrolysable organic nitrogen in rhizosphere soil of rice (Oryza sativa). Indian J. Agric. Sci. 75, 265-269.

Das, S.N., Dutta, S., Kondreddy, A., Chilukoti, N., Pullabhotla, S.V.S.R.N., Vadlamudi, S., Podile, A.R., 2010. Plant growth-promoting chitinolytic Paenibacillus elgii responds positively to tobacco root exudates. J. Plant Growth Regul. 29, 409-418.

Dhanda, S.S., Sethi, G.S., Behl, R.K., 2004. Indices of drought tolerance in wheat genotypes at early stages of plant growth. J. Agron. Crop Sci. 190 (1), 6-12

Egamberdiyeva, D., 2005. Effect of plant growth promoting bacteria on growth of Scots pine and silver birch seedlings. Uzbekistan J. Agric. 1 (19), 66-69.

Elo, S., Suominen, I., Kämpfer, P., Juhaoja, J., Salkinoja-Salonen, M., Haahtela, K., 2001. Paenibacillus borealis sp. nov., a nitrogen fixing species isolated from spruce forest humus in Finland. Int. J. Syst. Evol. Microbiol. 51, 535-545.

Farzana, Y., Saad, R.O.S., Kamaruzaman, S., 2009. Growth and storage root development of sweet potato inoculated with rhizobacteria under glass house conditions. Aust. J. Basic Appl. Sci. 3 (2), 1461-1466.

Gevrek, M.N., Atasoy, G.D., Yigit, A., 2012. Growth and yield response of rice (Oryza sativa L.) to different seed coating agents. Int. J. Agric. Biol. 14, 826-830.

Glick, B.R., 1995. The enhancement of plant-growth by free-living bacteria. Can. J. Microbiol. 41, 109-117

Gong, H.J., Randall, D.P., Flowers, T.J., 2006. Silicon deposition in the root reduces sodium uptake in rice (Oryza sativa L.) seedlings by reducing bypass flow. Plant Cell Environ. 29 (10), 1970-1979.

Guntzer, F., Keller, C., Meunier, J.D., 2012. Benefits of plant silicon for crops, a review. Agron. Sustain. Dev, 32 (1), 201-213.

Hamaker, B.R., Griffin, V.K., 1993. Effect of disulfide bond-containing protein on rice starch gelatinization and pasting. Cereal Chem. 70 (4), 377-380.

Hayat, R., Ali, S., Amara, U., Khalid, R., Ahmed, I., 2010. Soil beneficial bacteria and their role in plant growth promotion a review. Ann. Microbiol. 60, 579-598.

He, J., Ren, Y., Chen, X., Chen, H., 2014. Protective roles of nitric oxide on seed germination and seedling growth of rice (Oryza sativa L.) under cadmium stress. Ecotoxicol. Environ. Saf. 108, 114-119.

IRRI-International Rice Research Institute, 2004. Rice Knowledge bank International Year of rice.

Jamil, A., Riaz, S., Ashraf, M., Foolad, M.R., 2011. Gene expression profiling of plants under salt stress. Crit. Rev. Plant Sci. 30 (5), 435-458.

Javid, M.G., Sorooshzadeh, A., Moradi, F., Sanavy-Seyed, A.M.M., Allahdadi, I., 2011. The role of phytohormones in alleviating salt stress in crop plants. Aust. J. Crop Sci. 5 (6), 726-734

Jha, Y., Subramanian, R.B., Patel, S., 2011. Combination of endophytic and rhizospheric plant growth promoting rhizobacteria in Oryza sativa shows higher accumulation of osmoprotectant against saline stress. Acta Physiol. Plant. 33, 797-802.

Juliano, B.O., Villareal, C.P., 1993. Grain Quality Evaluation of World Rices. IRRI, Manila, Philippines

Jung, W.J., Jin, Y.L., Kim, K.Y., Park, R.D., Kim, T.H., 2005. Changes in pathogenesis-related proteins in pepper plants with regard to biological control of phytophthora blight with Paenibacillus illinoisensis. BioControl 50, $165-178$.
Kim, H.R., You, Y.H., 2010. The effects of the elevated $\mathrm{CO}_{2}$ concentration and increased temperature on growth, yield and physiological responses of rice (Oryza sativa L. cv. Junam). Adv. Biores. 1 (2), 46-50.

Kim, KY, Kwak, C.M. Lee, YW. Sa, T.M. 2014. Effect of co-inoculation of Brevibacterium iodinum RS16 and Methylobacterium oryzae CBMB20 on the early growth of crop plants in Saemangeum reclaimed soil. Korean J. Soil Sci. Fertil. 47 (1), 1-7.

Ladha, J.K., Reddy, P.M., 2003. Nitrogen fixation in rice systems, state of knowledge and future prospects. Plant Soil 252, 151-167.

Ladha, J.K., Bruijin, F.J., Malik, K.A., 1997. Introduction, assessing opportunities for nitrogen fixation in rice-a frontier project. Plant Soil 194, 1-10.

Lebuhn, M., Heulin, T., Hartmann, A., 1997. Production of auxin and other indolic and phenolic compounds by Paenibacillus polymyxa strains isolated from different proximity to plant roots. FEMS Microbiol. Ecol. 22, 325-334.

Liang, Y., 1999. Effects of silicon on enzyme activity and sodium, potassium and calcium concentration in barley under salt stress. Plant Soil 209, 217-224.

Linquist, B., van Groenigen, K.J., Pittelkow, C., van Kessel, C., 2011. An agronomic assessment of greenhouse gas emissions from major cereal crops. Glob. Change Biol. 18, 194-209.

Lisle, A.J., Martin, M., Fitzgerald, M.A., 2000. Chalky and translucent rice grains differ in starch composition and structure and cooking properties. Cereal Chem. 77, 627-632.

Long, H.H., Schmidt, D.D., Baldwin, I.T., 2008. Native bacterial endophytes promote host growth in a species-specific manner; phytohormone manipulations do not result in common growth responses. PLoS One 3 (7), e2702.

Lutts, S., Kinet, J.M., Bouharmont, J., 1995. Changes in plant response to $\mathrm{NaCl}$ during development of rice (Oryza sativus L.) varieties differing in salinity resistance. J. Exp. Bot. 46, 1843-1852.

Ma, J.F., 2004. Role of silicon in enhancing the resistance of plants to biotic and abiotic stresses. Soil Sci. Plant Nutr 50 (1), 11-18

Malik, K.A., Mirza, M.S., Hassan, U., Mehnaz, S., Rasul, G., Haurat, J., Bally, R. Normand, P., 2002. The role of plant-associated beneficial bacteria in rice-wheat cropping system. In: Kennedy, I.R., Choudhury, A.T.M.A. (Eds.), Biofertilisers in Action. Rural Industries Research and Development Corporation, Canberra, pp. 73-83.

Manivannan, M., 2011. Effect of PGPR as biofertilizer on growth and yield of paddy. Int. J. Pharm. Biol. Sci. Arch. 2, 6-10.

Mauad, M., Crusciol, C.A.C., Grassi Filho, H., Corrêa, J.C., 2003. Nitrogen and silicon fertilization of upland rice. Sci. Agricola 60 (4), 761-765.

Mitani, N., Ma, J.F., 2005. Uptake system of silicon in different plant species. J. Exp. Bot. 56, 1255-1261

Naing, K.W., Anees, M., Kim, S.J., Nam, Y., Kim, Y.C., Kim, K.Y., 2013. Characterization of antifungal activity of Paenibacillus ehimensis KWN38 against soilborne phytopathgenic fungi belonging to various taxonomic groups. Ann. Microbiol. 64, 55-63.

Nia, S.H., Zarea, M.J., Rejali, F., Varma, A., 2012. Yield and yield components of wheat as affected by salinity and inoculation with Azospirillum strains from saline or non-saline soil. J. Saudi Soc. Agric. Sci. 11, 113-121.

Pérez-Montãno, F., Alías-Villegas, C., Bellogín, R.A., del Cerro, P., Espuny, M.R. Jiménez-Guerrero, I., López-Baena, F.J., Ollero, F.J., Cubo, T., 2014. Plant growth promotion in cereal and leguminous agricultural important plants: from microorganism capacities to crop production. Microbiol. Res. 169, 325-336

Paul, D., 2012. Osmotic stress adaptations in rhizobacteria. J. Basic Microbiol. 52, $1-10$.

Qiao, J., Liu, Z., Deng, S., Ning, H., Yang, X., Lin, Z., Li, G., Wang, Q., Wang, S., Ding, Y., 2011. Occurrence of perfect and imperfect grains of six japonica rice cultivars as affected by nitrogen fertilization. Plant Soil 349, 191-202.

RDA (Rural Development Administration, Korea), 1988. Methods of Soil Chemical Analysis. National Institute of Agricultural Science and Technology, RDA, Suwon (in Korean).

Ramadoss, D., Lakkineni, V.K., Bose, P., Ali, S., Annapurna, K., 2013. Mitigation of salt stress in wheat seedlings by halotolerant bacteria isolated from saline habitats. SpringerPlus 2 (6), 1-7.

Ramesh, S.A., Tyerman, S.D., Xu, B., Bose, J., Kaur, S., Conn, V., Domingos, P., Ullah, S., Wege, S., Shabala, S., Feijoí, J.A., Ryan, P.R., Gillham, M., 2015. GABA signalling modulates plant growth by directly regulating the activity of plant-specific anion transporters. Nat. Commun. 6, 7879, http://dx.doi.org/10. 1038/ncomms8879.

Raza, W., Yang, X., Wu, H., Wang, Y., Xu, Y., Shen, Q., 2009. Isolation and characterisation of fusaricidin-type compound-producing strain of Paenibacillus polymyxa SQR-21 active against Fusarium oxysporum f.sp. nevium. Eur. J. Plant Pathol. 125, 471-483.

Sarangi, S.K., Maji, B., Singh, S., Burman, D., Mandal, S., Sharma, D.K., Singh, U.S. Ismail, A.M., Haefele, S.M., 2015. Improved nursery management further enhances the productivity of stress-tolerant rice varieties in coastal rainfed lowlands. Field Crops Res. 174, 61-70.

Scardaci, S.C., Eke, A.U., Hill, J.E., Shannon, M.C., Rhoades, J.D., 1996. Water and Soil Salinity Studies on California Rice. Rice Publication No. 2, Cooperative Extension. University of California, Colusa, CA.

Seckin, B., Sekmen, A.H., Turkan, I., 2009. An enhancing effect of exogenous mannitol on the antioxidant enzyme activities in roots of wheat under salt stress. Plant Growth Regul. 28, 12-20.

Singh, J.S., Pandey, V.C., Singh, D.P., 2011. Efficient soil microorganisms, a new dimension for sustainable agriculture and environmental development. Agric. Ecosyst. Environ. 140, 339-353. 
Sukweenadhi, J., Kim, Y.J., Lee, K.J., Koh, S.C., Hoang, V.A., Nguyen, N.L., Yang, D.C. 2014. Paenibacillus yonginensis sp. nov.: a potential plant growth promoting bacterium isolated from humus soil of Yongin forest. Antonie van Leeuwenhoek J. Microb. 106, 935-945.

Sukweenadhi, J., Kim, Y.J., Choi, E.S., Koh, S.C., Lee, S.W., Kim, Y.J., Yang, D.C., 2015 Paenibacillus yonginensis DCY84 ${ }^{\mathrm{T}}$ induces changes in Arabidopsis thaliana gene expression against aluminum, drought, and salt stress. Microbiol. Res. 172, 7-15.

Tabur, S., Demir, K., 2010. Role of some growth regulators on cytogenetic activity of barley under salt stress. Plant Growth Regul. 60, 99-104.

Tavares, L.C., Rufino, C.A., Dorr, C.A., Barros, A.S.A., Peske, S.T., 2012. Performance of lowland rice seeds coated with dolomitic limestone and aluminum silicate. Rev. Bras. Sementes 34, 202-211.

Timmusk, S., Wagner, E.G., 1999. The plant-growth-promoting rhizobacterium Paenibacillus polymyxa induces changes in Arabidopsis thaliana gene expression: a possible connection between biotic and abiotic stress responses. Mol. Plant Microbe Interact. 12, 951-959.

Timmusk, S., 2003. Mechanism of action of the plant growth promoting bacterium Paenibacillus polymyxa. In: PhD Thesis. Uppsala University, Uppsala, Sweden.

Trân Van, V., Berge, O., Kê, S.N., Balandreau, J., Heulin, T., 2000. Repeated beneficial effects of rice inoculation with a strain of Burkholderia vietnamiensis on early and late yield components in low fertility sulphate acid soils of Vietnam. Plant Soil 218, 273-284.

Tsujimoto, Y., Muranaka, S., Saito, K., Asai, H., 2014. Limited Si-nutrient status of rice plants in relation to plant-availableSi of soils nitrogen fertilizer application, and rice-growing environments across Sub-Saharan Africa. Field Crops Res. 155, 1-9.

Vidhyaskaran, P., Rabindran, R., Muthamilan, M., Nayar, K., Rajappan, K. Subramanian, N., Vasumathi, K., 1997. Development of a powder formulation of Pseudomonas fluorescens for control of rice blast. Plant Pathol. J. 46, 291-297.
Walsh, U.F., Morrissey, J.P., O'Gara, F., 2001. Pseudomonas for biocontrol of phytopathogens, from functional genomics to commercial exploitation. Curr. Opin. Biotechnol. 12, 289-295.

Weller, D.M., Raaijmakers, J.M., Gardener, B.B.M., Thomashow, L.S., 2002. Microbio populations responsible for specific soil suppressiveness to plant pathogens. Annu. Rev. Phytopathol. 40, 309-348.

Yang, J., Kloepper, J.W., Ryu, C.M., 2009. Rhizosphere bacteria help plants tolerate abiotic stress. Trends Plant Sci. 14, 1-4.

Yanni, Y.G., Rizk, R.Y., Abd El-Fattah, F.K., Squartini, A., Corich, V., Giacomini, A., de Bruijn, F., Rademaker, J., Maya-Flores, J., Ostrom, Vega-Hernandez, M.,

Hollingsworth, R.I., Martinez-Molina, E., Mateos, P.F., Velasquez, E., Triplett, E., Umali-Garcia, M., Anarna, J.A., Rolfe, B.G., Ladha, J.K., Hill, J., Mujoo, R., Ng, P.K., Dazzo, F.B., 2001. The beneficial plant growth-promoting association of Rhizobium leguminosarum bv: trifolii with rice roots. Aust. J. Plant Physiol. 28, $845-870$.

Yoshida, S., Forno, D.A., Cock, J.H., Gomez, K.A., 1976. Laboratory Manual for Physiological Studies of Rice, 3rd ed. International Rice Research Institutes, Manila.

Yun, B.W., Kim, M.G., Handoyo, T., Kim, K.M., 2014. Analysis of rice grain quality-associated quantitative trait loci by using genetic mapping. Am. J. Plant Sci. 5, 1125-1132.

van Loon, L.C., Bakker, P., Pieterse, C.M.J., 1998. Systemic resistance induced by rhizosphere bacteria. Annu. Rev. Phytopathol. 36, 453-483.

von der Weid, I., Frois-Duarte, G., van Elsas, J.D., Seldin, L., 2002. Paenibacillus brasilensis sp. nov.: a novel nitrogen-fixing species from the maize rhizosphere in Brazil. Int. J. Syst. Evol. Microbiol. 52, 2147-2153. 